\title{
How does extraction of biologically active substances with supercritical carbon dioxide affect lignocellulosic biomass properties?
}

\section{Mariusz Jerzy Stolarski, et al. [full author details at the end of the article]}

Received: 4 September 2019 / Published online: 4 May 2020

(c) The Author(s) 2020

\begin{abstract}
In the bio-based economy concept, any biomass should not be used directly for energy purposes without considering the possibility of using it for bioproducts with higher added value. Extractable phytochemicals found in lignocellulosic biomass of perennial industrial crops (PIC) are used in the pharmaceutical, cosmetics, chemical, food and feed industries. Therefore, these compounds should be obtained first, and only the so-called PIC extraction biomass should be used, for example, for the production of bioenergy. An efficient low-energy and environmentally friendly method of extracting phytochemicals from the plant biomass is supercritical carbon dioxide $\left(\mathrm{scCO}_{2}\right)$ extraction. The aim of the study was to assess the thermophysical properties and chemical composition of 19 types of PIC biomass previously subjected to two types of $\mathrm{scCO}_{2}$ extraction compared to the biomass before extraction. The biomass after pure $\mathrm{scCO}_{2}$ and $\mathrm{scCO}_{2} / \mathrm{H}_{2} \mathrm{O}(1 \mathrm{wt} \%$ ) extraction contained less ash (by 4.9 and $11.3 \%$ ), carbon (by 3.1 and $7.8 \%$ ), hydrogen (by 5.8 and $8.9 \%$ ), nitrogen (by 4.5 and 6.8\%), sulfur (by 3.8 and 3.8\%), lignin (by 5.4 and 1.1\%), hemicellulose (by 14.4\%) and more chlorine (by 4.7 and $15.3 \%$ ) compared to the biomass before extraction. In addition, the biomass after extraction with pure $\mathrm{scCO}_{2}$ contained more cellulose and was characterized by lower moisture content and higher heating value and lower heating value. However, the biomass after $\mathrm{scCO}_{2} / \mathrm{H}_{2} \mathrm{O}$ extraction contained more substances soluble in cold and hot water. Generally, the bark of four short-rotation coppice (SRC) species was characterized by a high content of nitrogen, sulfur, substances soluble in cold and hot water, other soluble substances and at the same time low cellulose content (26-28\% d.m.). In turn, the wood of all SRC species was characterized by a high cellulose content (51-56\% d.m.). However, all herbaceous crops and grasses contained more chlorine, hemicellulose and generally less lignin compared to the SRC biomass. To assess the practical suitability of the PIC biomass extraction for the production of bioenergy (solid, liquid or gaseous biofuels), further research is needed.
\end{abstract}

Electronic supplementary material The online version of this article (https://doi.org/10.1007/s00226-02 0-01182-5) contains supplementary material, which is available to authorized users. 


\section{Introduction}

Perennial industrial crops (PICs), which include short-rotation coppice (SRC), herbaceous crops and grasses are one of the lignocellulosic biomass sources (Christian et al. 2008; Stolarski et al. 2013a, 2014, 2017; Sabatti et al. 2014; Ceotto et al. 2015, 2016; Monti et al. 2015; Matyka and Kuś 2016). It should be emphasized that currently the use of the PIC biomass is associated mainly with its use for energy purposes, in order to generate thermal and electrical energy or transport biofuels using various conversion technologies (Godin et al. 2013; Stolarski et al. 2013b, 2015a; Jankowski et al. 2016; Scordia et al. 2016). However, the future direction of using the PIC lignocellulosic biomass is the production of various renewable bioproducts, as part of a bio-based economy. The bio-based economy consists of all possible production paths for food and non-food products as well as energy services from biomass and requires a balanced supply of various biomass types for the production of bioproducts with multidirectional use. In the bio-based economy concept, each biomass, including the PIC lignocellulosic biomass, should be used in a sustainable manner. This means that it should not be used directly for energy purposes without considering the possibility of its use for high-value bioproducts. It should be emphasized that extractable phytochemicals found in PIC lignocellulosic biomass are used in industry, for example, pharmaceutical, cosmetics, chemical, food and feed (Attard et al. 2018; Bonaterra et al. 2010; Conde et al. 2014; Devappa et al. 2015; McElroy et al. 2017; Noleto-Dias et al. 2018; Parajuli et al. 2015; Sergent et al. 2014; Vázquez et al. 2012). Therefore, PIC lignocellulosic biomass should be obtained first and only residues, the so-called post-extraction biomass, should be used, for instance, for bioenergy production. The efficient low-energy and environmentally friendly method of extracting phytochemicals from the plant biomass is a supercritical carbon dioxide $\left(\mathrm{scCO}_{2}\right)$ extraction (Rój 2014). In addition, the use of $\mathrm{scCO}_{2}$ extraction removes significant amounts of lipids and resin acids that easily undergo autoxidation, which consequently improves the safety of biofuel, for example, less off-gassing of wood pellets (Attard et al. 2016, 2018). However, in order to consider the energy use of post-extraction biomass, it is necessary to know about its parameters, which are important for the production of solid, liquid or gaseous biofuels. The literature lacks information on the thermophysical and chemical properties of the PIC post-extraction biomass, from which biologically active substances have been extracted. Therefore, the aim of this research was to assess the thermophysical properties and chemical composition of 19 types of PIC lignocellulosic biomass previously subjected to two types of $\mathrm{scCO}_{2}$ extraction in comparison with the biomass not subjected to the extraction.

\section{Materials and methods}

\section{Acquisition and preparation of biomass}

The PICs were grown in field experiments located in northeastern Poland, on land owned by the University of Warmia and Mazury in Olsztyn. The studies were carried out on 11 PIC genotypes, including four species of short-rotation coppice (SRC): 
Salix viminalis L., Ekotur variety; S. purpurea L.; Populus nigra $\times$ P. maximowiczii Henry cv. Max-5; and Robinia pseudoacacia L.; three species of herbaceous crops: Helianthus salicifolius A. Dietr; Silphium perfoliatum L.; and H. tuberosus L.; but also four species of grasses: Miscanthus $\times$ giganteus J.M. Greef \& M. Deuter; $M$. sacchariflorus ((Maxim.) Hack.); M. sinensis ((Thunb.) Andersson); and Spartina pectinata Bosc ex Link (Table 1).

The PIC lignocellulosic biomass was obtained in the winter period in the third decade of February 2018, from 1-year shoots formed on 7-year-old stumps (which were the plant stems from the entire growing period of 2017). The biomass of all genotypes was obtained using the brushcutter. In the case of four SRC species, three types of biomass were prepared, including bark, wood and a mixture of bark and wood. For this purpose, whole SRC shoots were cut out, followed by the bark mechanical separation from the wood. In this way, bark (b) and wood (w) were obtained. However, whole stems obtained directly from the plantations were used to obtain a mixture of bark and wood $(b+w)$. Thus, 12 types of the biomass derived from SRC $(4$ species $\times 3$ biomass types $=12$ ) were obtained in total. In the case of three genotypes of herbaceous crops (semi-wood) and four genotypes of grass (straw), the biomass was the whole shoots. Therefore, 19 samples of PIC lignocellulosic biomass were used for the studies (Table 1).

Table 1 The studied species and types of perennial industrial crops (PIC) biomass

\begin{tabular}{llll}
\hline Id & PIC group & Species/variety or clone & Biomass type \\
\hline 1 & Short-rotation coppice & S. viminalis, Ekotur variety & Bark (b) \\
2 & & Wood (w) \\
3 & & Bark + wood (b + w) \\
4 & & & Bark (b) \\
5 & & Wood (w) \\
6 & & P. nigra $\times$ P. maximowiczii, Max-5 clone & Bark + wood (b + w) \\
7 & & & Bark (b) \\
8 & & Wood (w) \\
9 & & R. pseudoacacia & Bark + wood (b +w) \\
10 & & & Bark (b) \\
11 & & Wood (w) \\
12 & & H. salicifolius & Bark + wood (b +w) \\
13 & Herbaceous crops & S. perfoliatum & Semi-wood (s-w) \\
14 & & H. tuberosus & Semi-wood (s-w) \\
15 & & M. $\times$ giganteus & Semi-wood (s-w) \\
16 & Grasses & M. sinensis & Straw (s) \\
17 & & M. sacchariflorus & Straw (s) \\
18 & & S. pectinata & Straw (s) \\
19 & & & Straw (s) \\
\hline
\end{tabular}




\section{Supercritical fluid extraction}

Each biomass was dried in a dryer at $40^{\circ} \mathrm{C}$ for 7 consecutive days to achieve a moisture content below $10 \%$, followed by grinding in a hammer mill using a 1-mm sieve. After grinding the biomass, representative samples (approx. $0.5 \mathrm{~kg}$ ) were collected for laboratory analyses of the raw material (prior to the extraction). Each of the 19 biomass samples (approx. $11 \mathrm{~kg}$ ) was divided into two parts and subjected to the extraction of bioactive substances with carbon dioxide in a supercritical state. The extraction was performed with pure carbon dioxide $\left(\mathrm{scCO}_{2}\right)$ as well as with the addition of water as a co-solvent $\left[\mathrm{scCO}_{2} / \mathrm{H}_{2} \mathrm{O}(1 \mathrm{wt} \%)\right]$. The supercritical fluid extraction was performed on a pilot plant with two extractors of $40 \mathrm{dm}^{3}$ each, working under the pressure of up to 1000 bar and temperature up to $100{ }^{\circ} \mathrm{C}$. Each raw material $(5 \mathrm{~kg})$ was extracted with $\mathrm{scCO}_{2}$ and $\mathrm{scCO}_{2} / \mathrm{H}_{2} \mathrm{O}$ under the same parameters, which were set as follows: temperature at $40{ }^{\circ} \mathrm{C}$ and pressure at 330 bar.

After the extraction, representative samples (approx. $0.5 \mathrm{~kg}$ ) of post-extraction residues were collected for laboratory analyses. It should be noted here that the choice of species and obtained biomass, the date of sampling and methods for extraction of bioactive substances are a part of the research project (see Acknowledgements).

\section{Laboratory analyses}

The samples (approx. $100 \mathrm{~g}$ each) of initial PIC biomass (19 samples) and the postextraction biomass (38 samples) were isolated in the laboratory in accordance with standard PN-EN ISO 14780:2017-07. The biomass moisture content was then determined at $105{ }^{\circ} \mathrm{C}$ by a drying-weight method (PN-EN ISO 18134-1:2015) using a laboratory dryer (FD BINDER series, Tuttlingen, Germany). After moisture determination, the dried biomass samples were ground in an analytical mill using a 1-mm sieve (Retsch SM 200, Haan, Germany). Subsequently, the biomass samples were stored in closed laboratory containers. The higher heating value (HHV) of biomass was determined in the IKA C2000 calorimeter (Taufen, Germany) based on the dynamic method. The lower heating value (LHV) (PN-EN ISO 18125:2017-07) was calculated on the basis of HHV, moisture and hydrogen content. The ash content in the biomass was determined in the ELTRA TGA-THERMOSTEP automatic analyzer (Neuss, Germany) using the PN-EN ISO 18122:2016-01 standard.

As a part of the study, the elemental composition of biomass, the content of carbon $(\mathrm{C})$, hydrogen $(\mathrm{H})$ and sulfur $(\mathrm{S})$ were determined using the ELTRA CHS-500 automatic analyzer (Neuss, Germany) (PN-EN ISO 16948:2015-07 and PN-EN ISO 16994:2016-10). In addition, the total nitrogen (N) was determined in the biomass by the Kjeldahl method using the K-435 mineralization apparatus and the BUCHI B-324 distillery apparatus (Flawil, Switzerland). The chlorine content was determined according to the PN-ISO 587:2000 standard. After samples burning in a NABERTHERM muffle furnace (Lilienthal, Germany) at a temperature of $650{ }^{\circ} \mathrm{C}$ in the presence of an Eschka's mixture, the sample of an aqueous extract was titrated

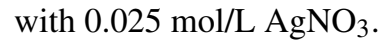


The content of soluble substances in cold water was determined by weight based on the differences in the mass of the samples before and after the extraction. Samples placed in F57 filtration bags (ANKOM Technology) were extracted with distilled water $\left(20-25^{\circ} \mathrm{C}\right.$ ) for $48 \mathrm{~h}$. Then, they were rinsed twice in the ANKOM A200 apparatus (NY, USA) and dried before weighing $\left(105^{\circ} \mathrm{C}\right)$. Weighed samples were used for further analyses. Similarly, the content of soluble substances in hot water was determined. In this case, the samples were extracted for $3 \mathrm{~h}$ at $100{ }^{\circ} \mathrm{C}$ and dried prior to weighing at $105^{\circ} \mathrm{C}$. An analytical balance with accuracy to $0.1 \mathrm{mg}$ was used to weigh the samples.

After determination of substances soluble in hot water, laboratory analyses were performed to determine the NDF (neutral detergent fiber) (PN-EN ISO 16472:2007), ADF (acid detergent fiber) and ADL (acid detergent lignin) fractions (PN-EN ISO 13906:2009) in the biomass using the Ankom A200 extraction system. On the basis of differences in the obtained results, the content of lignin, cellulose and hemicellulose in the tested samples was calculated. The calculation methods are shown below.

The content of compounds soluble in cold water (CW) (1):

$$
\mathrm{CW}(\%)=100-\left(100 \cdot \frac{W_{\mathrm{CW}}-W_{1}}{W_{2}}\right)
$$

The content of compounds soluble in hot water (HW) (2):

$$
\mathrm{HW}(\%)=100-\left(100 \cdot \frac{W_{\mathrm{HW}}-W_{1}}{W_{2}}\right)
$$

The content of neutral detergent fiber (NDF) (3):

$$
\operatorname{NDF}(\%)=\frac{100 \cdot\left(W_{\mathrm{NDF}}-W_{1} \cdot C\right)}{W_{2}}
$$

The content of acid detergent fiber (ADF) (4):

$$
\operatorname{ADF}(\%)=\frac{100 \cdot\left(W_{\mathrm{ADF}}-W_{1} \cdot C\right)}{W_{2}}
$$

The content of acid detergent lignin (ADL) (5):

$$
\operatorname{ADL}(\%)=\frac{100 \cdot\left(W_{\mathrm{ADL}}-W_{1}-W_{A}\right)}{W_{2}}
$$

where $W_{1}$ is the bag tare weight $(\mathrm{g}), W_{2}$ - sample weight $(\mathrm{g}), W_{\mathrm{CW}}$-dried weight of bag and samples after extraction in cold water $(\mathrm{g}), W_{\mathrm{HW}}$ - dried weight of bag and samples after extraction in hot water $(\mathrm{g}), W_{\mathrm{NDF}}$ - dried weight of bag with fiber after NDF extraction $(\mathrm{g}), W_{\mathrm{ADF}}$ - dried weight of bag with fiber after ADF extraction (g), $C$-blank bag correction (running average of final oven-dried weight divided by original blank bag weight), $W_{\mathrm{ADL}}$ - dried weight of bag with fiber after ADL extraction $(\mathrm{g}), W_{\mathrm{A}}$-weight of residue after incineration of the filter bag and samples at $520{ }^{\circ} \mathrm{C}(\mathrm{g})$. 
The content of hemicellulose, cellulose and lignin was determined as follows $(6,7$, 8):

$$
\begin{gathered}
\text { Hemicellulose content }(\%)=\operatorname{NDF}(\%)-\operatorname{ADF}(\%) \\
\text { Cellulose content }(\%)=\operatorname{ADF}(\%)-\operatorname{ADL}(\%) \\
\text { Lignin content }(\%)=\operatorname{ADL}(\%)
\end{gathered}
$$

On the basis of the content of individual fractions, the content of other soluble substances (in neutral detergents-SLS and EDTA) was calculated using Formula (9):

$$
\text { Other soluble substances }(\%)=100-\mathrm{HW}(\%)-\mathrm{NDF}(\%)
$$

\section{Statistical analysis}

Two-factor analysis of variance in a fixed model was used for statistical data analyses. The significance of differences between means was assessed by Tukey's HSD test with $P<0.05$. Additionally, in order to generalize a large number of results, two separate one-way analyses of variance were also performed. The first of these analyses compared in general two types of extraction (after pure $\mathrm{scCO}_{2}$ and after $\mathrm{scCO}_{2} / \mathrm{H}_{2} \mathrm{O}$ ) and biomass before extraction, regardless of the plant species. In the second one-way analysis, the main PIC groups were compared regardless of the type of extraction. The obtained results were collected in the form of means and homogenous groups of the Tukey's HSD test with $P<0.05$. A multi-dimensional principal component analysis (PCA) with varimax rotation was also applied. All analyses were performed using the STATISTICA 13.3 package (TIBCO Software Inc. 2017).

\section{Results and discussion}

\section{Chemical composition}

\section{Fiber and water-soluble fractions}

The content of soluble substances in cold and hot water, other soluble substances, hemicellulose, cellulose and lignin was significantly differentiated by both extraction type and biomass type and the interactions between these main factors (Table 2). The content of substances soluble in cold water in biomass after $\mathrm{scCO}_{2} / \mathrm{H}_{2} \mathrm{O}$ extraction was significantly higher $(10.7 \% \mathrm{~d} . \mathrm{m}$. on average) compared to the biomass before extraction and after pure $\mathrm{scCO}_{2}$ extraction, by 19 and $32 \%$ on average (Table 3 ).

It was found that among the tested types of biomass, the content of substances soluble in cold water was by far the highest in the SRC bark and ranged from 13.8 to $26.2 \%$ d.m., respectively, for $R$. pseudoacacia (b) after extraction with pure $\mathrm{scCO}_{2}$ and 


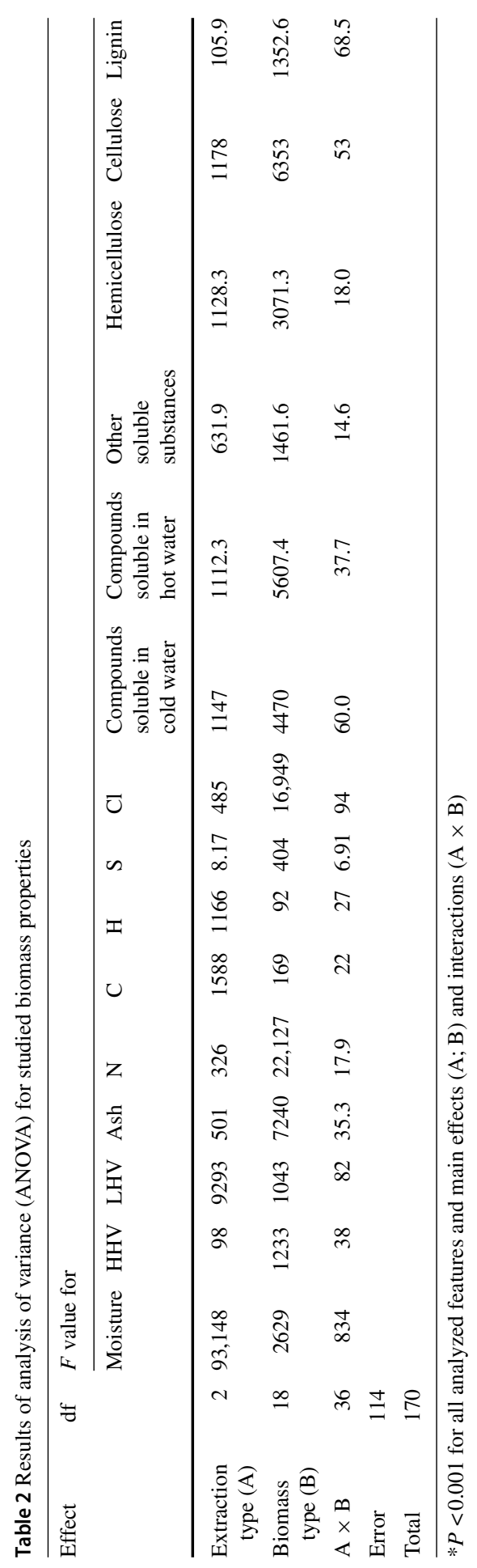


Table 3 Average values of all tested biomass features and their relative changes (\%) after pure $\mathrm{scCO}_{2}$ and $\mathrm{scCO}_{2} / \mathrm{H}_{2} \mathrm{O}$ extraction relative to biomass before extraction*

\begin{tabular}{|c|c|c|c|c|c|c|}
\hline Item & Unit & $\begin{array}{l}\text { Biomass } \\
\text { before } \\
\text { extraction }\end{array}$ & $\begin{array}{l}\text { Biomass } \\
\text { after pure } \\
\mathrm{scCO}_{2} \\
\text { extraction }\end{array}$ & $\begin{array}{l}\text { Relative } \\
\text { changes } \\
(\%)\end{array}$ & $\begin{array}{l}\text { Biomass } \\
\text { after } \\
\mathrm{scCO}_{2} / \mathrm{H}_{2} \mathrm{O} \\
\text { extraction }\end{array}$ & $\begin{array}{l}\text { Relative } \\
\text { changes } \\
(\%)\end{array}$ \\
\hline $\begin{array}{r}\text { Moisture } \\
\text { content }\end{array}$ & $\%$ & $6.08^{b}$ & $3.69^{c}$ & -39.3 & $7.55^{\mathrm{a}}$ & 24.2 \\
\hline Ash & $\%$ d.m. & $2.65^{\mathrm{a}}$ & $2.52^{b}$ & -4.9 & $2.35^{\mathrm{c}}$ & -11.3 \\
\hline HHV & $\begin{array}{l}\mathrm{MJ} \mathrm{kg}^{-1} \\
\text { d.m. }\end{array}$ & $19.22^{b}$ & $19.26^{\mathrm{a}}$ & 0.2 & $19.17^{\mathrm{c}}$ & -0.3 \\
\hline LHV & $\mathrm{MJ} \mathrm{kg}^{-1}$ & $16.73^{b}$ & $17.33^{\mathrm{a}}$ & 3.6 & $16.49^{c}$ & -1.4 \\
\hline $\mathrm{C}$ & $\%$ d.m. & $55.69^{\mathrm{a}}$ & $53.96^{\mathrm{b}}$ & -3.1 & $51.37^{\mathrm{c}}$ & -7.8 \\
\hline $\mathrm{H}$ & $\%$ d.m. & $6.06^{\mathrm{a}}$ & $5.71^{\mathrm{b}}$ & -5.8 & $5.52^{\mathrm{c}}$ & -8.9 \\
\hline $\mathrm{N}$ & $\%$ d.m. & $0.88^{\mathrm{a}}$ & $0.84^{b}$ & -4.5 & $0.82^{\mathrm{c}}$ & -6.8 \\
\hline S & $\%$ d.m. & $0.053^{\mathrm{a}}$ & $0.051^{\mathrm{b}}$ & -3.8 & $0.051^{\mathrm{b}}$ & -3.8 \\
\hline $\mathrm{Cl}$ & $\%$ d.m. & $0.085^{\mathrm{c}}$ & $0.089^{\mathrm{b}}$ & 4.7 & $0.098^{\mathrm{a}}$ & 15.3 \\
\hline $\begin{array}{l}\text { Compounds } \\
\text { soluble in } \\
\text { cold } \\
\text { water }\end{array}$ & $\%$ d.m. & $8.94^{b}$ & $8.06^{c}$ & -9.8 & $10.67^{a}$ & 19.4 \\
\hline $\begin{array}{c}\text { Compounds } \\
\text { soluble in } \\
\text { hot water }\end{array}$ & $\%$ d.m. & $11.99^{b}$ & $10.92^{\mathrm{c}}$ & -8.9 & $13.70^{\mathrm{a}}$ & 14.3 \\
\hline $\begin{array}{l}\text { Other } \\
\text { soluble } \\
\text { sub- } \\
\text { stances }\end{array}$ & $\%$ d.m. & $6.03^{c}$ & $8.43^{\mathrm{a}}$ & 39.8 & $8.23^{b}$ & 36.5 \\
\hline Hemicellulose & $\%$ d.m. & $21.47^{\mathrm{a}}$ & $18.38^{b}$ & -14.4 & $18.37^{\mathrm{b}}$ & -14.4 \\
\hline Cellulose & $\%$ d.m. & $44.38^{\mathrm{b}}$ & $47.02^{\mathrm{a}}$ & 5.9 & $43.76^{\mathrm{c}}$ & -1.4 \\
\hline Lignin & $\%$ d.m. & $16.12^{\mathrm{a}}$ & $15.25^{\mathrm{c}}$ & -5.4 & $15.95^{\mathrm{b}}$ & -1.1 \\
\hline
\end{tabular}

*Detailed numerical data for all types of before extraction biomass and post-extraction biomass are presented in supplementary material in Tables S1 to S15

$\mathrm{a}, \mathrm{b}, \mathrm{c}$ - the values in the lines marked with the same letter do not differ statistically (Tukey's HSD test with $P<0.05)$

P. nigra $\times$ P. maximowiczii (b) in the biomass before extraction (Fig. 1). Lower values of this characteristic were found in the whole SRC biomass (average range from 5.6 to $9.9 \%$ d.m.), and even lower in wood (average range from 4.4 to $6.9 \%$ d.m.). In turn, in herbaceous crops biomass, the content of substances soluble in cold water ranged from 5.4 to $7.6 \%$ d.m. on average, for $S$. perfoliatum and $H$. salicifolius, respectively. However, the lowest value of this trait (on average $2.3 \% \mathrm{~d} . \mathrm{m}$ ) was determined in the biomass of $S$. pectinata grass.

The content of substances soluble in hot water was generally higher compared to the content of substances soluble in cold water. On the other hand, the content of other soluble substances was higher in the post-extraction biomass compared with the 


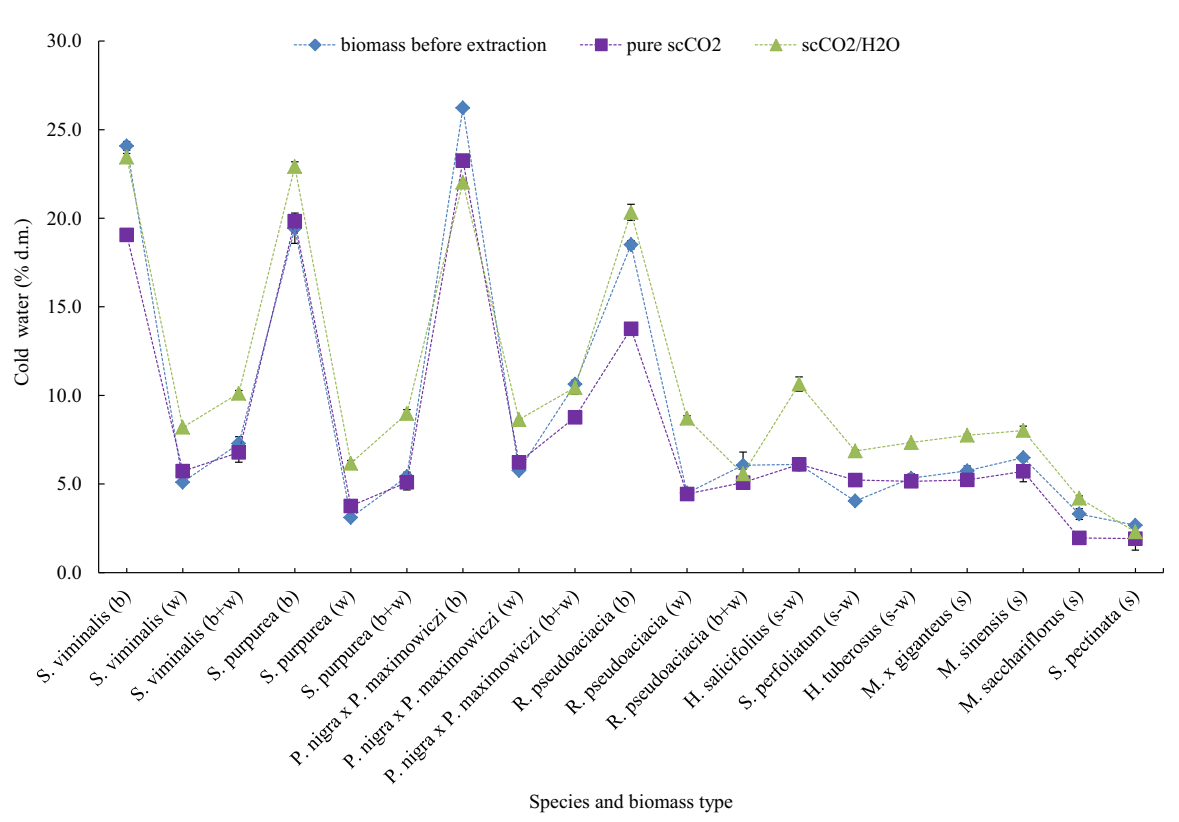

Fig. 1 Content of cold water-soluble substances in various types of perennial industrial crops biomass depending on the type of extraction; diamond markers-biomass before extraction, square markers-biomass after pure $\mathrm{scCO}_{2}$ extraction, triangle markers-biomass after $\mathrm{scCO}_{2} / \mathrm{H}_{2} \mathrm{O}$ extraction; (b)—bark; (w)—wood; (b + w) —bark and wood, meaning the whole biomass; (s-w)—semi-wood; (s) - straw. Error bars represent standard deviation

biomass before extraction (Table 3). In other studies, the most soluble substances in cold (12.70\% d.m.) and hot (19.64\% d.m.) water and in the ethanol-benzene mixture ( $10.01 \%$ d.m.) were determined in the bark of 1-year-old willow shoots (Stolarski et al. 2005). In the cited study, the 1-year-old debarked willow shoots contained less of these compounds compared to bark and non-debarked shoots from 1-year and 2-year-old willow. On the other hand, the least soluble substances in cold (1.42\% d.m.) and hot ( $3.90 \%$ d.m.) water were found in the wood of 4-year non-debarked shoots.

The hemicellulose content ( $21.5 \%$ d.m. on average) in the biomass before extraction was significantly higher by approx. $14.4 \%$ compared to the biomass after pure $\mathrm{scCO}_{2}$ and $\mathrm{scCO}_{2} / \mathrm{H}_{2} \mathrm{O}$ extraction (Table 3 ). Among the tested types of the biomass, S. pectinata grass was characterized by the highest content of hemicellulose (36-39\% d.m.) (Fig. 2). Other grass species also had a high hemicellulose content, although it was lower in the range of 6 to $10 \mathrm{pp}$ compared to $S$. pectinata. In the herbaceous crops, the hemicellulose content ranged from 15.5 to $22.3 \%$ d.m. in H. tuberosus after pure $\mathrm{scCO}_{2}$ extraction and $\mathrm{H}$. salicifolius before extraction, respectively. However, among the SRC, the high content of this feature (on average over $20 \%$ d.m.) was determined in wood $(\mathrm{w})$ and in the whole biomass $(\mathrm{b}+\mathrm{w})$ of $R$. pseudoacacia. The lowest hemicellulose content was found in the SRC bark, ranging on average from 9 to $13 \%$ d.m., for $S$. viminalis and R. pseudoacacia, respectively. In other studies, the content of this compound in the 3-year-old willow biomass was higher (26.9\% d.m. 


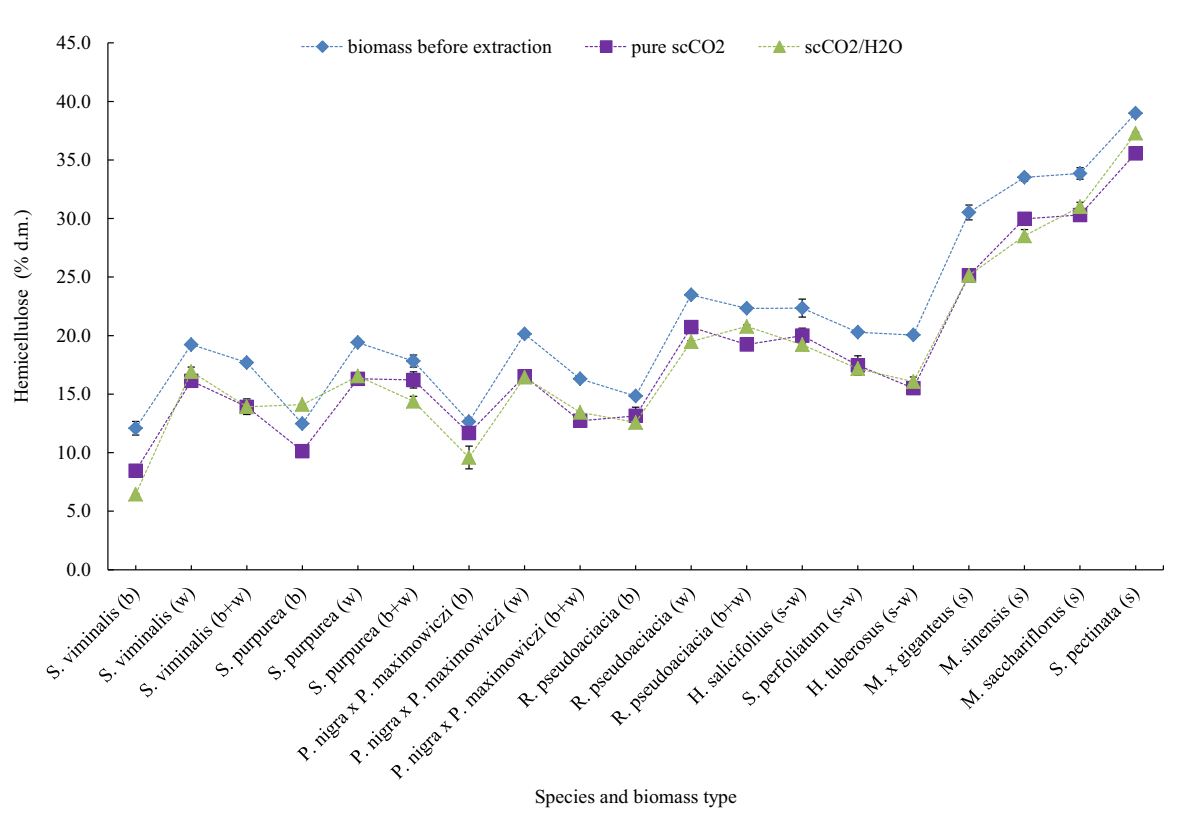

Fig. 2 Content of hemicellulose in various types of perennial industrial crops biomass depending on the type of extraction; explanations-see Fig. 1

on average) compared to the values obtained for the SRC biomass in the present study (Krzyżaniak et al. 2014). An equally high content of hemicellulose (26.2\% d.m.) was also determined in older poplar wood (Przybysz et al. 2018). However, its content in $M . \times$ giganteus biomass $(25.9 \%$ d.m. $)$ was close to the average value obtained in the present research.

The cellulose content ( $47.0 \% \mathrm{~d}$.m. on average) of the biomass after pure $\mathrm{scCO}_{2}$ extraction was significantly higher compared to the biomass before and after $\mathrm{scCO}_{2} / \mathrm{H}_{2} \mathrm{O}$ extraction by approx. 6 and $7 \%$, respectively (Table 3). Among the tested types of biomass, the wood (w) of $S$. viminalis and $S$. purpurea had the highest cellulose content (on average approx. 56\% d.m.). A particularly high content of this compound was found after extraction with pure $\mathrm{scCO}_{2}, 57.8$ and $58.4 \%$ d.m., respectively, for $S$. viminalis (w) and S. purpurea (w) (Fig. 3), whereas the cellulose content in the wood of other SRC species was lower from 2 to $7 \mathrm{pp}$ depending on the type of extraction. In turn, the cellulose content of the whole SRC biomass $(b+w)$ ranged from 42.7 to $52.5 \%$ d.m., respectively, for $P$. nigra $\times$ P. maximowiczii after $\mathrm{scCO}_{2} / \mathrm{H}_{2} \mathrm{O}$ extraction and $R$. pseudoacacia after pure $\mathrm{scCO}_{2}$ extraction. Among the herbaceous crops and grasses, the highest cellulose content was also determined in the biomass of $H$. tuberosus $(53.6 \%$ d.m.) and M. $\times$ giganteus $(52.8 \%$ d.m.) after extraction with pure $\mathrm{scCO}_{2}$. Among all tested types of biomass, the SRC bark was characterized by the lowest cellulose content (below 30\% d.m.). Another research reports that the cellulose content in willow bark was lower than in wood and in the whole biomass (Stolarski et al. 2005). In the cited study, the effect of the age of the willow shoots on cellulose content was demonstrated and the lowest content of this compound was also 


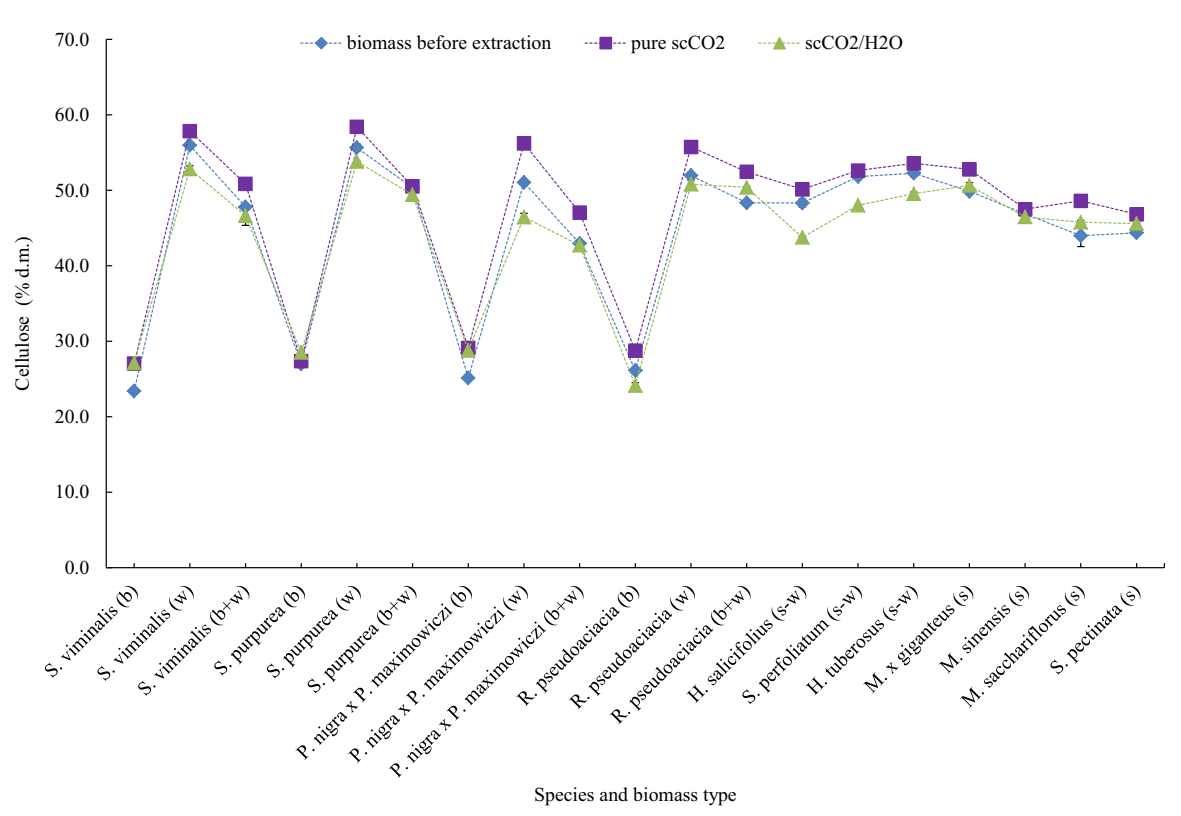

Fig. 3 Content of cellulose in various types of perennial industrial crops biomass depending on the type of extraction; explanations-see Fig. 1

found in all biomass of 1-year shoots (41.5\% d.m.), and in 2- and 4-year shoots, this value was higher by about $44.8 \%$ d.m. It was also shown that the cellulose content can be significantly differentiated by willow species, variety and clone (Krzyżaniak et al. 2014). The average content of this compound in 3-year-old willow shoots was $44.4 \%$ d.m. and ranged from 42.3 to $47.6 \%$ d.m., respectively, for $S$. dasyclados, clone UWM 155, and S. viminalis, Ekotur variety (previously UWM 043 clone). The high cellulose content (52.4\% d.m.) was determined in wood of older poplar ('Hybrid 275' cultivar). However, its content in M. $\times$ giganteus biomass was $47.2 \%$ d.m. (Przybysz et al. 2018).

The average lignin content $(16.1 \%$ d.m.) in the biomass before extraction was significantly higher by 1.1 and $5.4 \%$ compared to the biomass after $\mathrm{scCO}_{2} / \mathrm{H}_{2} \mathrm{O}$ and pure $\mathrm{scCO}_{2}$ extraction, respectively (Table 3 ). Among the tested types of biomass, $R$. pseudoacacia bark (b) was characterized by the highest content of lignin (26.6-23.8\% d.m.) (Fig. 4). The bark of the remaining SRC species contained less lignin in the range of 2 to even $13 \mathrm{pp}$, and the lowest value of this trait $(11.0 \%$ d.m.) was found in $S$. purpurea (b) after $\mathrm{scCO}_{2} / \mathrm{H}_{2} \mathrm{O}$ extraction. In contrast, the lignin content in the whole SRC biomass ranged from 17.3 to $20.9 \%$ d.m. for $R$. pseudoacacia biomass after pure $\mathrm{scCO}_{2}$ extraction and $S$. purpurea biomass before extraction, respectively. In the group of herbaceous crops, the lignin content was lower and ranged from 11.5 to $17.3 \%$ d.m. for S. perfoliatum biomass before extraction and H. tuberosus biomass after both types of extraction, respectively. The biomass of the grasses had an even lower content of lignin, and the lowest value ( $8.15 \%$ d.m.) was determined in $M$. sinensis biomass after extraction with pure $\mathrm{scCO}_{2}$. According to the literature data, the lignin content in the 


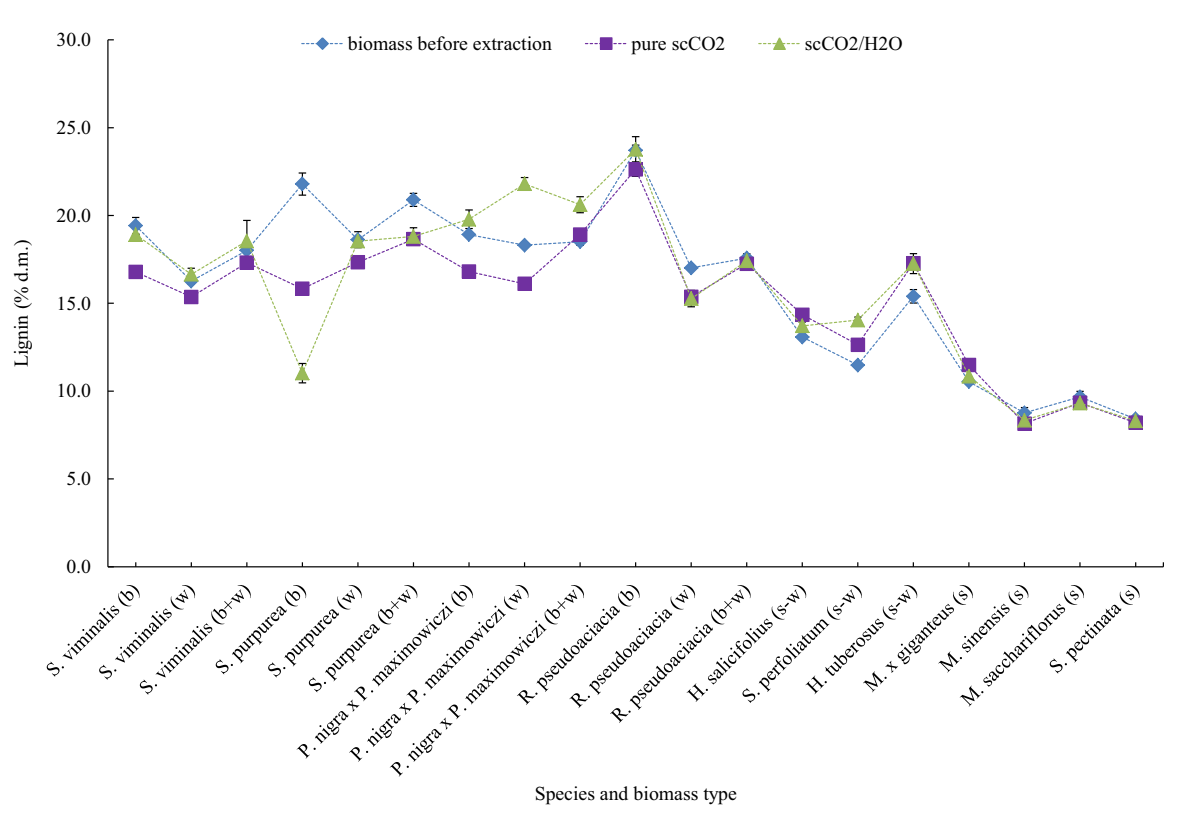

Fig. 4 Content of lignin in various types of perennial industrial crops biomass depending on the type of extraction; explanations-see Fig. 1

willow bark of S. viminalis (37\% d.m.) was almost two times higher than in wood (approx. 20\% d.m.) and the whole biomass (approx. 22\% d.m.) (Stolarski et al. 2005). An even higher lignin content was found in 3-year-old willow shoots, on average about $25 \%$ d.m. (Krzyżaniak et al. 2014). In turn, the lignin content in the wood of poplar 'Hybrid 275' cultivar was $18.0 \%$ d.m., whereas in $M . \times$ giganteus it was lower only by 0.2 pp compared with poplar (Przybysz et al. 2018).

It should also be added that in the present studies, hemicellulose loss in biomass after both supercritical extractions was greater than that of cellulose and lignin. The hemicellulose loss was due to its much greater susceptibility to degradation under the influence of $\mathrm{scCO}_{2}$ and water, compared to other fiber fractions, which was also found in other studies (Haghighi Mood et al. 2013; Morais et al. 2015). Cellulose is a more durable polymer than hemicellulose; therefore, a slight loss in biomass was observed in most of the tested species, but only in the $\mathrm{scCO}_{2}$ /water extraction variant. Under conditions of high pressure, carbon dioxide with water forms carbonic acid, which catalyzes the hydrolysis reaction of polysaccharides. However, hydrolysis results in a high efficiency at temperatures above $100{ }^{\circ} \mathrm{C}$ (Morais et al. 2015). Lignin is an aromatic polymer and has hydrophobic properties. Lignocellulosic biomass is delignified during extraction using organic solvents and $\mathrm{scCO}_{2}$ at temperatures above $150{ }^{\circ} \mathrm{C}$ (Neata et al. 2015; Pasquini et al. 2005; Schrems et al. 2012). Therefore, in the present studies, a higher degree of lignin removal was observed in the case of pure $\mathrm{scCO}_{2}$ extraction than $\mathrm{scCO}_{2} /$ water. The degree of delignification and hydrolysis of cellulose and hemicellulose was much lower than in the works cited above, because the extraction studied here was carried out at a lower temperature and pressure. In the present 
research, biomass delignification was not the purpose of supercritical extraction. It should also be emphasized that the observed $\mathrm{C}$ and $\mathrm{H}$ loss was associated with the extraction of organic compounds with a higher $\mathrm{C}$ and $\mathrm{H}$ content than cellulose and hemicellulose. These compounds include such classes as fats, fatty acids, resin acids, waxes, hydrocarbons and polyphenols. Their isolation from lignocellulosic biomass was the main goal of the supercritical extraction process; therefore, a slight decrease in $\mathrm{C}$ and $\mathrm{H}$ content in post-extraction biomass was observed. On the other hand, it should be emphasized that in order to learn the exact mechanisms of cellulose, hemicellulose, lignin and element removal by supercritical extraction, additional, more detailed studies are needed.

\section{Elemental composition}

The elemental composition of biomass, including the content of carbon, hydrogen, sulfur and chlorine was significantly differentiated by both the type of extraction and the type of biomass and the interaction between these main factors (Table 2). The content of carbon in biomass before extraction (approx. 55.7\% d.m.) was significantly higher in comparison with the biomass after extraction with pure $\mathrm{scCO}_{2}$ and $\mathrm{scCO}_{2} / \mathrm{H}_{2} \mathrm{O}$ by on average 3.1 and $7.8 \%$, respectively (Table 3). Among the studied biomass, the wood of $P$. nigra $\times P$. maximowiczii was characterized by the highest content of carbon (average 56.5\% d.m.) (Fig. 5). In general, the wood (w) of all SRC species was characterized by a higher carbon content as compared to its total biomass content (b $+w$ ) and bark (b). In turn, the content of carbon in herbaceous crops and grasses biomass was at a level similar to the SRC bark. According to other studies, among 26 PIC genotypes tested, the carbon content was also higher in the SRC biomass as compared to herbaceous crops and grasses (Stolarski et al. 2018). However, the marked contents of this element were lower and ranged from 47.8 to $52.8 \%$ d.m., respectively for S. perfoliatum and P. balsamifera UWM 2. Moreover, in the studies on 165 willow clones, the carbon content was on average at the level of 50-51\% d.m. (Krzyżaniak et al. 2015; Stolarski et al. 2015b).

Similar to the content of carbon, the content of hydrogen in the biomass before extraction (on average $6.1 \%$ d.m.) was significantly higher compared with the biomass after extraction with pure $\mathrm{scCO}_{2}$ and $\mathrm{scCO}_{2} / \mathrm{H}_{2} \mathrm{O}$, by on average 5.8 and $8.9 \%$, respectively (Table 3). Among the types of biomass studied, the highest hydrogen content (6.2\% d.m.) was analyzed for $R$. pseudoacacia, whereas the lowest $(5.4 \%$ d.m.) for $S$. perfoliatum (Fig. 6). Generally, the SRC biomass was characterized by a higher content of hydrogen as compared to herbaceous crops and grasses. Similar relationships were found in other studies in which the highest hydrogen content was found in the biomass of P. balsamifera UWM 2 (on average 6.2\% d.m.), and the lowest in the biomass of S. perfoliatum (5.6\% d.m.) (Stolarski et al. 2018). Based on the literature data, a high hydrogen content was determined in willow biomass (7.1\% d.m.) (Cuiping et al. 2004).

The content of nitrogen in the biomass before extraction (average $0.88 \%$ d.m.) was also significantly higher by 4.5 and $6.8 \%$ in comparison with the biomass after extraction with pure $\mathrm{scCO}_{2}$ and $\mathrm{scCO}_{2} / \mathrm{H}_{2} \mathrm{O}$, respectively (Table 3). Among the tested types of biomass, the highest nitrogen content was found in the bark of $R$. pseudoacacia 


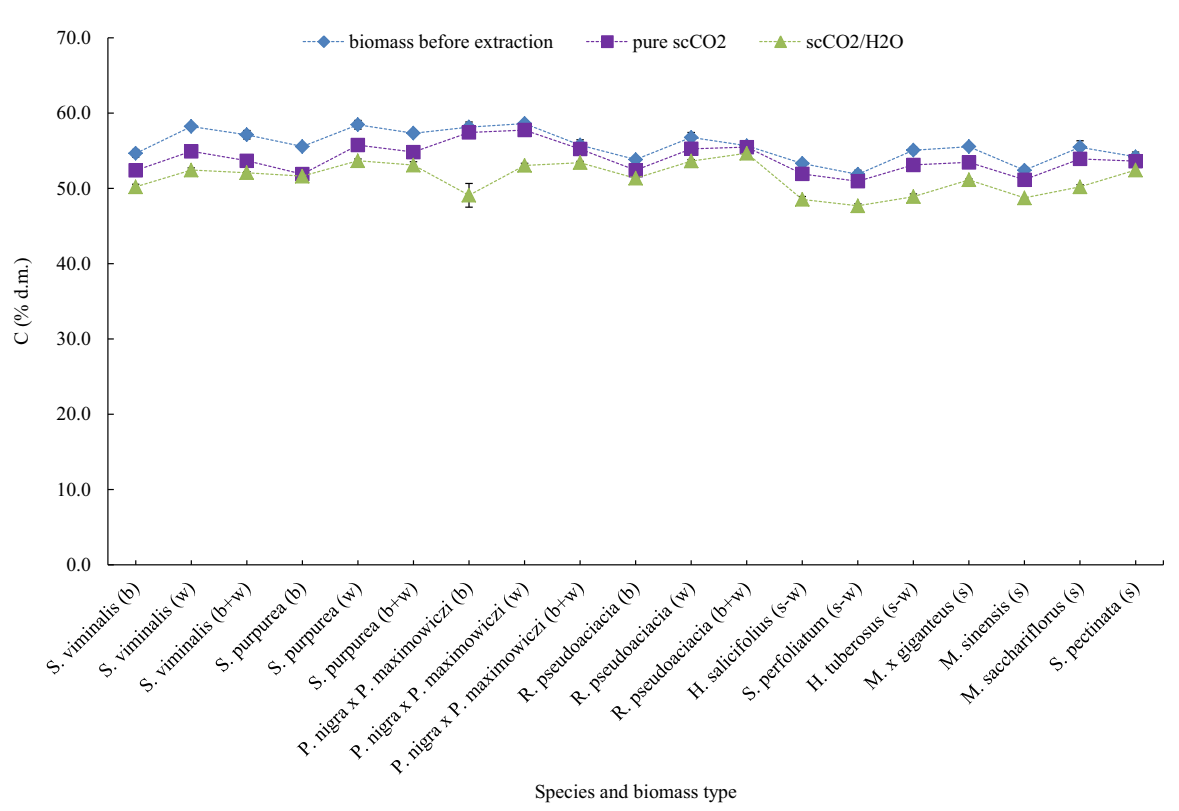

Fig. 5 Content of carbon in various types of perennial industrial crops biomass depending on the type of extraction; explanations-see Fig. 1

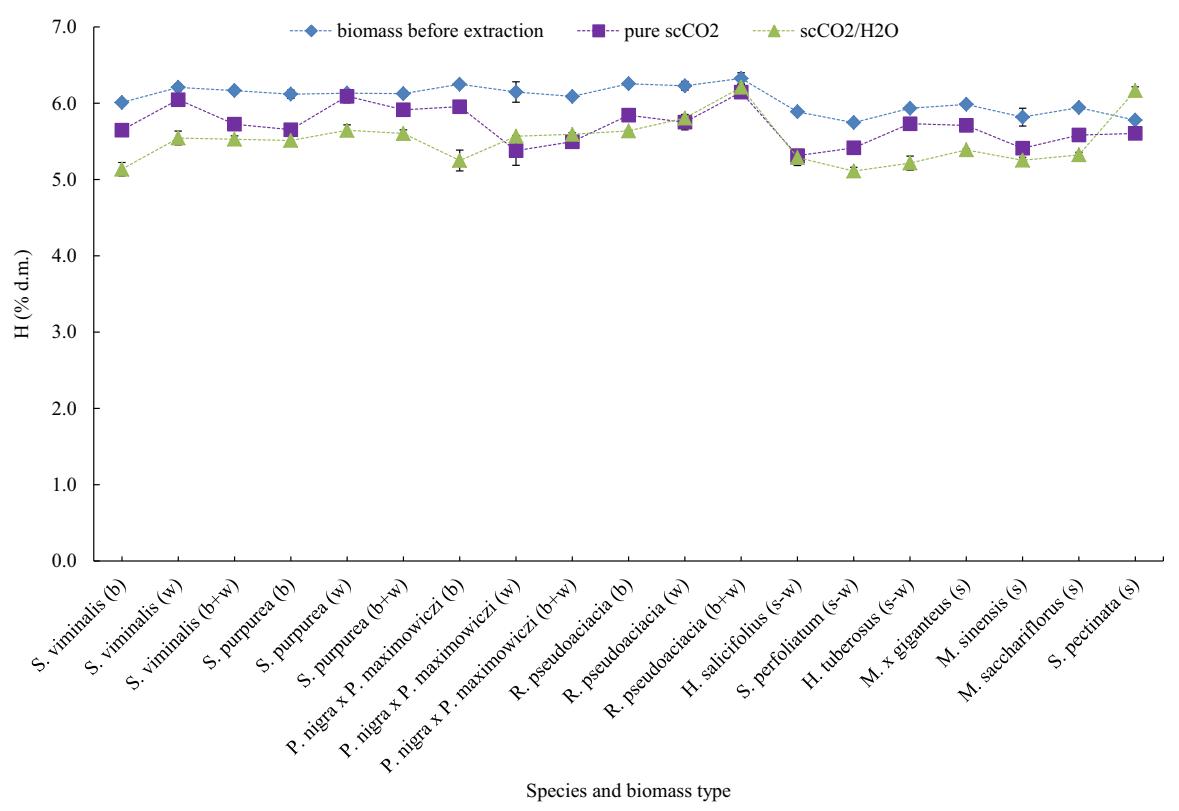

Fig. 6 Content of hydrogen in various types of perennial industrial crops biomass depending on the type of extraction; explanations-see Fig. 1 


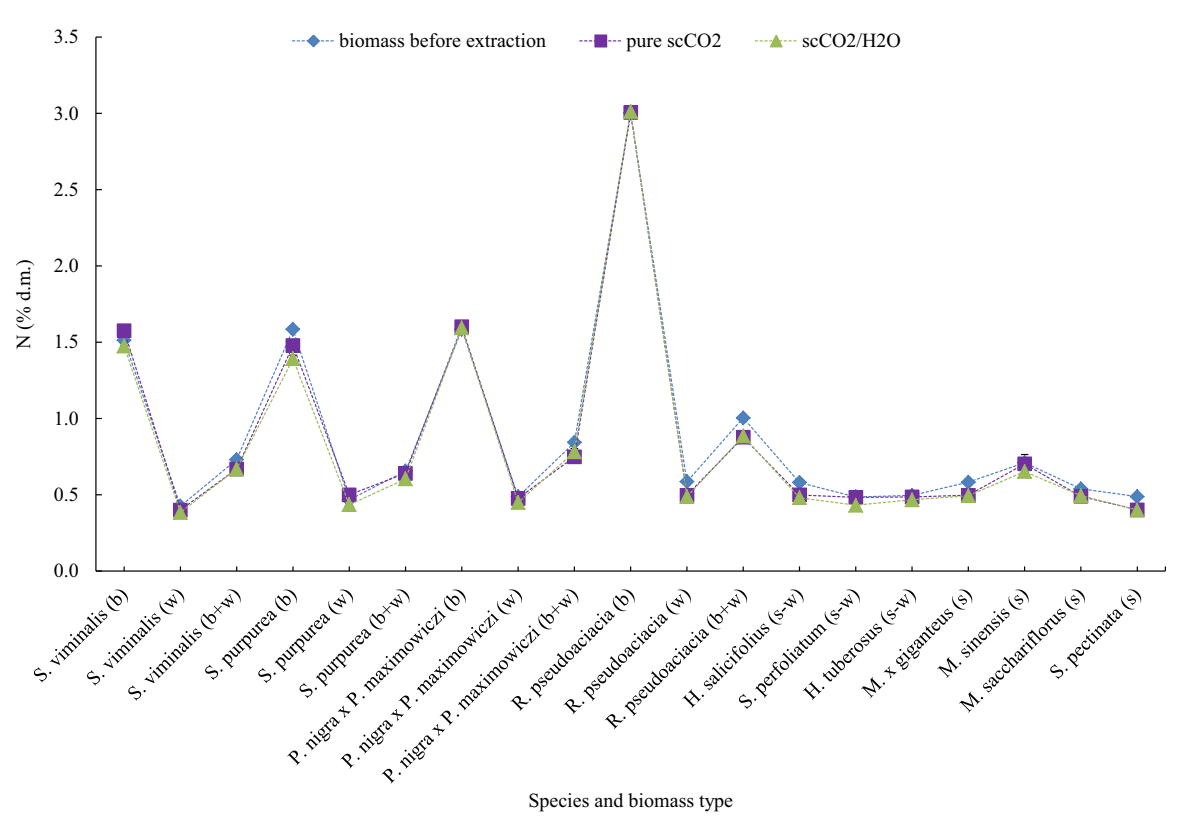

Fig. 7 Content of nitrogen in various types of perennial industrial crops biomass depending on the type of extraction; explanations-see Fig. 1

(Fig. 7). Significantly, lower nitrogen content in the range from 0.4 to $0.5 \% \mathrm{~d} . \mathrm{m}$. was found in the SRC wood. As for herbaceous crops and grasses biomass, the content of nitrogen ranged from 0.43 to $0.69 \%$ d.m. for $S$. pecinata and $M$. sinensis, respectively. Stolarski et al. (2018) reported that among the 26 PIC species tested, the highest nitrogen content (approx. $1.5 \%$ d.m.) was determined in the biomass of $R$. pseudoacacia. However, in the majority of tested biomass, the average content of this element was below $1 \%$ d.m., whereas the lowest was on average $0.35 \%$ d.m. (S. hermaphrodita).

The content of sulfur was higher by on average $3.8 \%$ in the biomass before extraction than in the two types of post-extraction biomasses (Table 3 ). The higher sulfur content was clearly visible in the bark of all SRC species (range from 0.074 to $0.102 \%$ d.m.) compared to other types of biomass (Fig. 8). The grasses were characterized by lower sulfur content in the range of 17 to even $115 \%$ than in the SRC bark. Values similar to that in grasses were analyzed in the whole SRC biomass $(b+w)$. In the case of the herbaceous crops biomass, the content of this element was on average below $0.04 \%$ d.m. However, by far the lowest value was in a pure SRC wood, on average from 0.023 to $0.038 \%$ d.m. in P. nigra x P. maximowiczii (w) and S. viminalis (w), respectively. Other studies also present significantly lower sulfur content in the SRC wood compared to bark (Stolarski et al. 2005). In contrast, in comparative studies of 26 PIC genotypes, by far the highest content of this element was found in the biomass of A. donax, on average $0.135 \%$ d.m., and the lowest in S. hermaphrodita, on average $0.031 \%$ d.m. (Stolarski et al., 2018). However, the analysis conducted on several hundreds of different willow and poplar clone biomasses revealed that the sulfur content was similar to that obtained in the present research and was approx. 


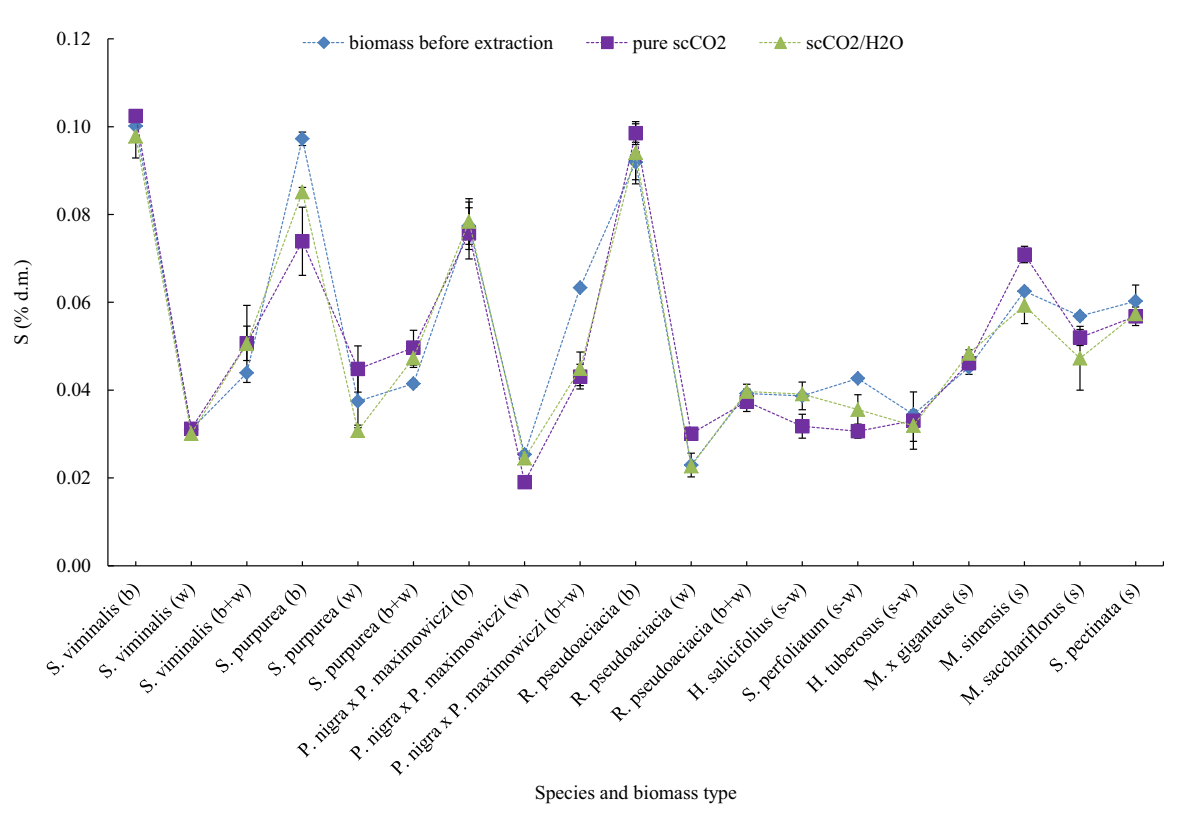

Fig. 8 Content of sulfur in various types of perennial industrial crops biomass depending on the type of extraction; explanations-see Fig. 1

0.05\% d.m. (Krzyżaniak et al. 2015; Stolarski et al. 2015b; Monedero et al. 2016). Moreover, the sulfur content in the biomass in the present research and in the cited literature was very low compared to solid fossil fuels, as, for instance, the sulfur content in hard coal is in the range from 0.45 to even over 1\% d.m. (Stolarski et al. 2013c; Wang et al. 2016).

The chlorine content was the lowest in the biomass before extraction, on average $0.085 \%$ d.m. (Table 3). However, in the biomass after pure $\mathrm{scCO}_{2}$ and $\mathrm{scCO}_{2} / \mathrm{H}_{2} \mathrm{O}$ extraction, it was higher by 4.7 and $15.3 \%$, respectively. By far, the highest chlorine content (from 0.241 to $0.294 \%$ d.m.) was found in the biomass of $H$. salicifolius and for all three species of Miscanthus (Fig. 9). In another grass species, S. pectinata, the chlorine content was also high, on average approx. $0.110 \%$ d.m. However, significantly lower content of this element was found in S. perfoliatum from the group of herbaceous crops but also in all types of the SRC biomass.

\section{Thermophysical properties of biomass}

All studied thermophysical properties of biomass (moisture content, HHV, LHV and ash content) were influenced by both the type of extraction and the type of biomass and the interaction between these main factors (Table 2). The biomass of all 19 analyzed samples after pure $\mathrm{scCO}_{2}$ extraction was characterized by significantly lower moisture content (average 3.7\%) compared to the biomass before extraction (average 6.1\%) and that after $\mathrm{scCO}_{2} / \mathrm{H}_{2} \mathrm{O}$ extraction (average 7.6\%) (Fig. 10, Table 3). In the case of extraction with pure carbon dioxide, the lowest moisture content was analyzed for the 


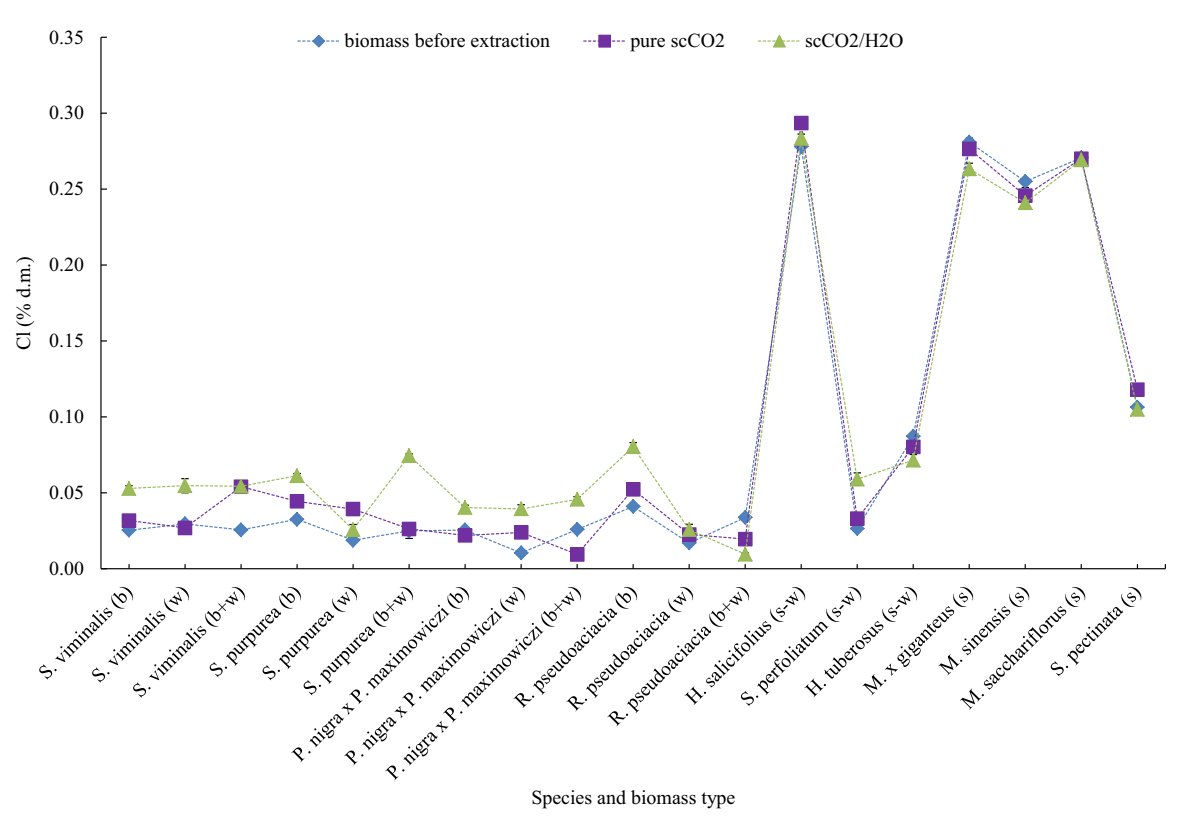

Fig. 9 Content of chlorine in various types of perennial industrial crops biomass depending on the type of extraction; explanations—-see Fig. 1

wood of $R$. pseudoacacia (2.4\%) and the highest for the bark of S. viminalis (5.7\%). On the other hand, the moisture content of the biomass before and after $\mathrm{scCO}_{2} / \mathrm{H}_{2} \mathrm{O}$ extraction was in the range of $4.5-8.8 \%$ and $4.3-9.6 \%$, respectively.

Certainly, it should be added here that the very low moisture content of the analyzed biomass before extraction was due to the earlier thermal drying of the biomass as was required for the extraction. However, after the extraction with pure $\mathrm{scCO}_{2}$, further reduction in moisture content in the range of 2-3 percentage points (pp) was observed. On the other hand, in the case of the second type of extraction $\left(\mathrm{scCO}_{2} / \mathrm{H}_{2} \mathrm{O}\right)$, with water addition to carbon dioxide, the final moisture after extraction was also at the low level. This means that in the supercritical fluid extraction significant amounts of water from each type of biomass were discharged. Therefore, it can be concluded that after both types of extraction $\left(\mathrm{scCO}_{2}\right.$ and $\left.\mathrm{scCO}_{2} / \mathrm{H}_{2} \mathrm{O}\right)$, the biomass moisture will be below $10 \%$, which means that it can be successfully used for further processes or can be stored without losing its properties or values. This is very important because the moisture of PIC biomass harvested directly from the plantation is definitely higher and depends on the plant species, the type of biomass, weather conditions during harvesting but also the date of harvesting (Stolarski et al. 2014, 2018). It was shown that among the SRC, particularly high moisture during harvesting may be observed for the biomass of poplar (53-62\%), slightly lower for the biomass of willow (47-59\%) and the lowest for the biomass of black locust (40-48\%) (Krzyżaniak et al. 2015; Stolarski et al. 2013a, 2018; Nielsen et al. 2015; Gasol et al. 2010; Sabatii et al. 2014). On the other hand, the moisture content of the biomass from the herbaceous crops and grasses decreased as the harvest time was delayed, and at the end of March, it was at 


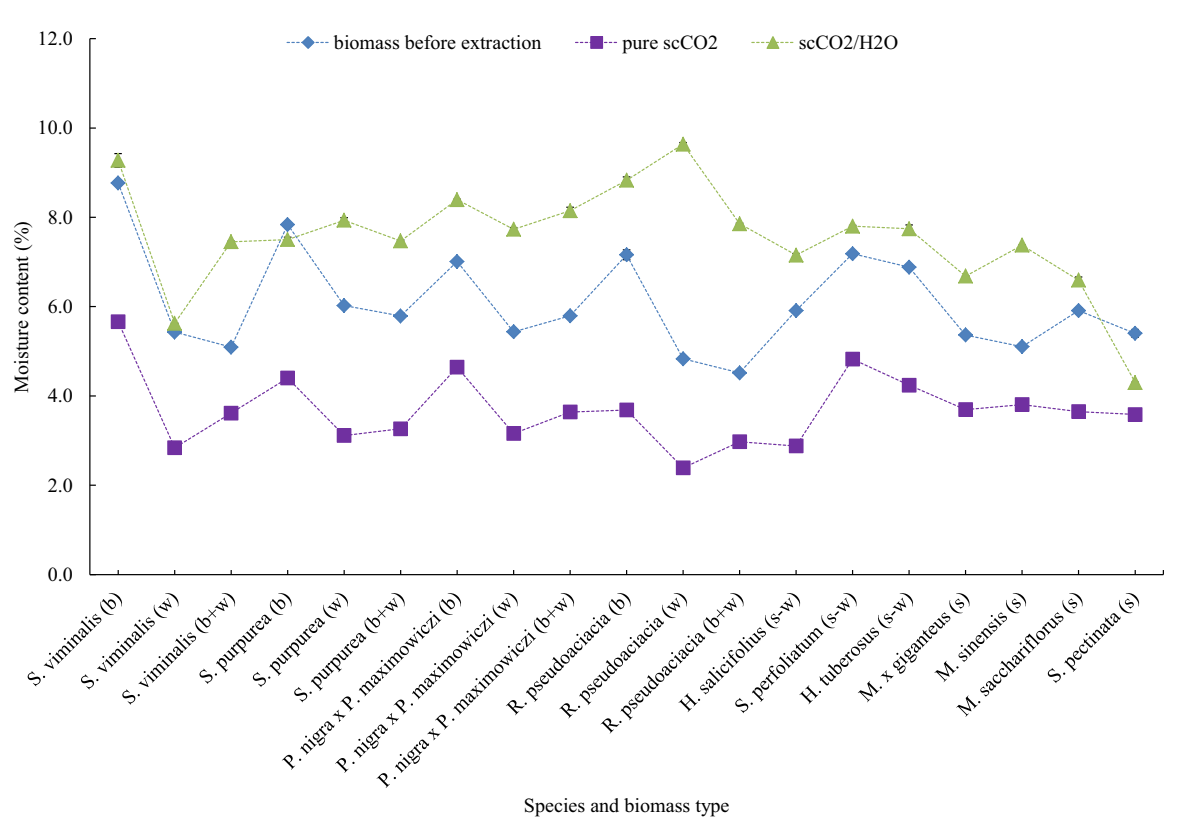

Fig. 10 Moisture content of various types of perennial industrial crops biomass depending on the type of extraction; explanations—see Fig. 1

the lowest level, even below 20\% (Stolarski et al. 2014, 2018). The extraction with carbon dioxide in a supercritical state was used for dewatering of green wood before drying in an oven for less wood distortion (Dawson and Pearson 2017).

The ash content in the biomass before extraction was the highest, on average $2.65 \%$ of dry matter (d.m.). The biomass extraction with pure $\mathrm{scCO}_{2}$ and $\mathrm{scCO}_{2} / \mathrm{H}_{2} \mathrm{O}$ reduced the average ash content by 4.9 and $11.3 \%$, respectively (Table 3). However, not all biomass types were characterized by the reduction in ash content as a result of the extraction. Among the analyzed types of biomass, the highest content of ash was observed for the bark of $R$. pseudoacacia, on average $5.0 \%$ d.m. (Fig. 11). It should be noted that in the case of the SRC biomass, the content of ash in the bark (b) was significantly higher compared to its content in wood (w) and in the mixture of bark and wood $(b+w)$, even up to 5-8 times and 2-4 times higher, respectively than in wood (w) and bark + wood $(b+w)$. The ash content in herbaceous crops biomass ranged from 2.8 to $4.3 \%$ d.m. in the biomass of $H$. tuberosus and $S$. perfoliatum, respectively. On the other hand, the value of this feature in the biomass of grasses was in the average range from 2.5 to $4.1 \% \mathrm{~d} . \mathrm{m}$. in $M . \times$ giganteus and $M$. sinensis, respectively. It should be emphasized, however, that the lowest ash content (in the range from 0.6 to $0.8 \%$ d.m.) among all biomass species was found in SRC wood, respectively for $S$. purpurea and $P$. nigra $\times P$. maximowiczii. In addition, the ash content in the whole SRC biomass $(b+w)$ was significantly lower $(1.1-1.7 \%$ d.m.) compared to the ash content in the biomass of herbaceous crops and grasses. Similar relations between the ash content in the SRC biomass of herbaceous crops and grasses were found in other studies (Stolarski et al. 2014, 2018). 


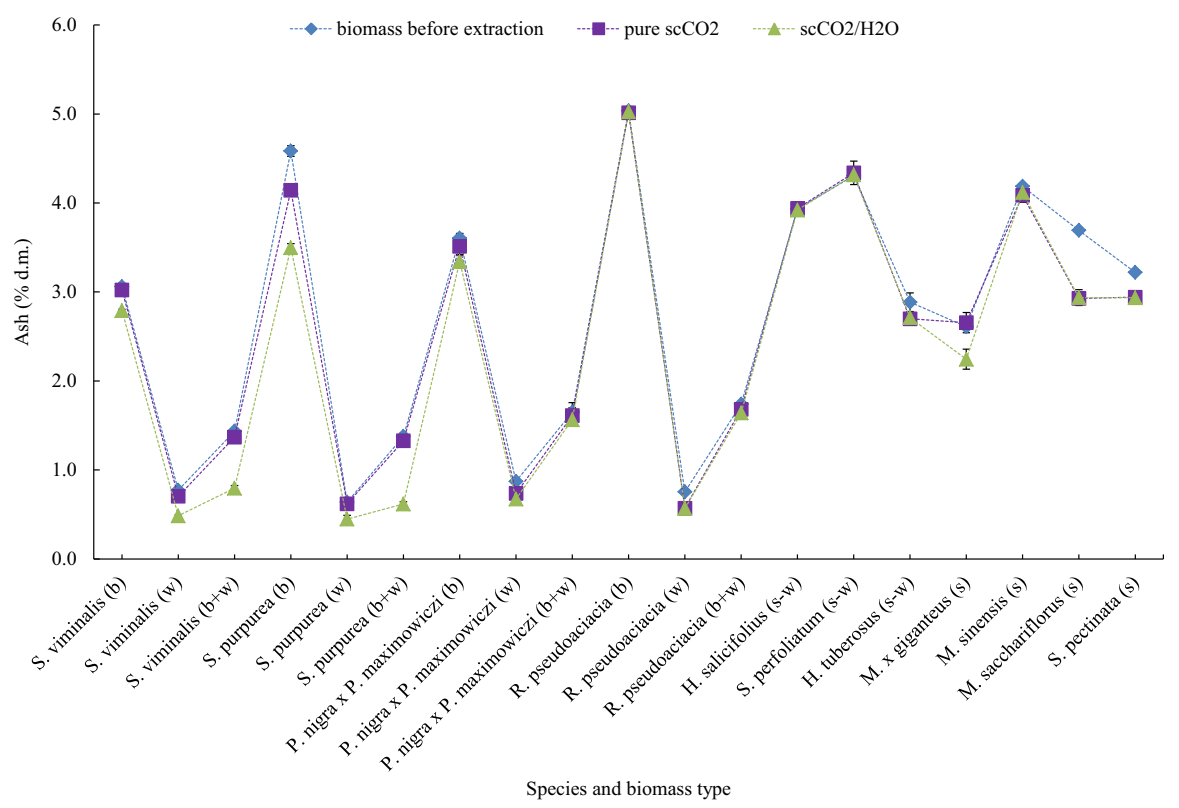

Fig. 11 Ash content in various types of perennial industrial crops biomass depending on the type of extraction; explanations-see Fig. 1

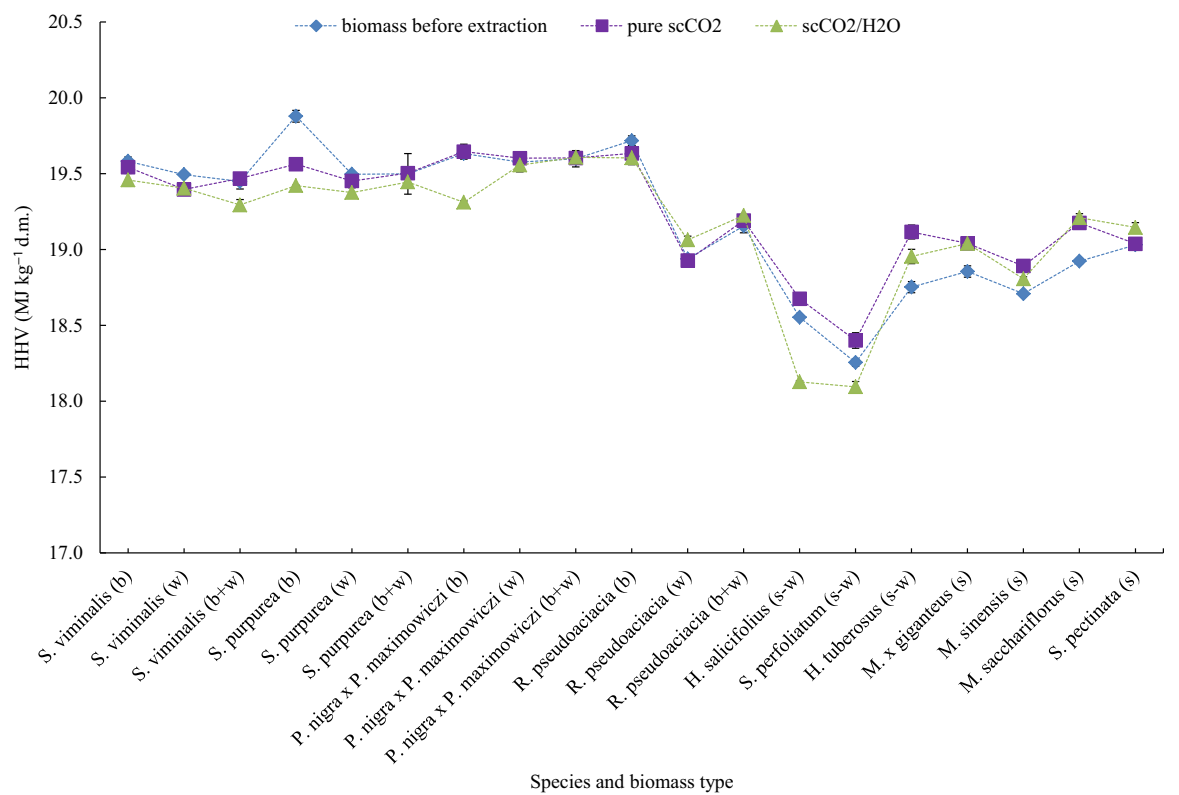

Fig. 12 Higher heating value of various types of perennial industrial crops biomass depending on the type of extraction; explanations-see Fig. 1 


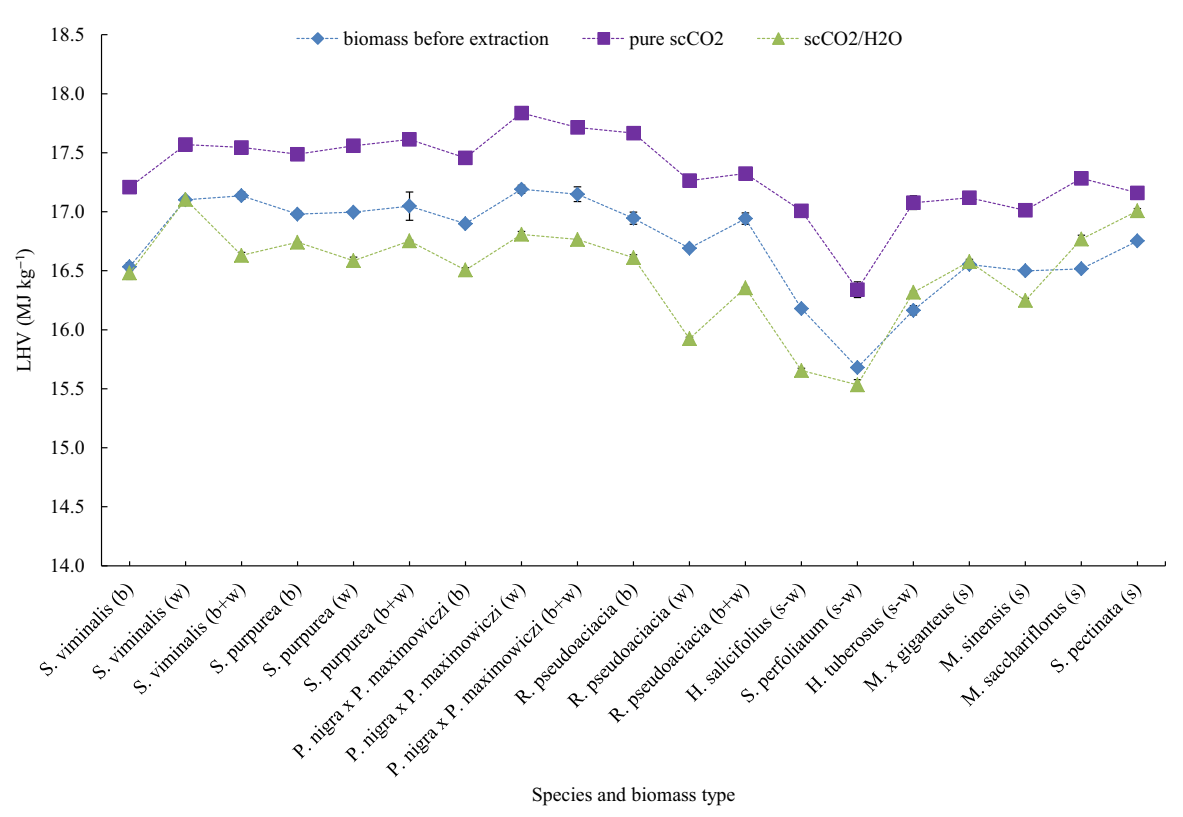

Fig. 13 Lower heating value of various types of perennial industrial crops biomass depending on the type of extraction; explanations-see Fig. 1

The biomass after extraction with pure $\mathrm{scCO}_{2}$ was characterized by higher $\mathrm{HHV}$ and LHV values in comparison with the biomass before extraction and $\mathrm{CO}_{2} / \mathrm{H}_{2} \mathrm{O}$ extraction (Table 3). However, it should be noted that in the case of HHV, the differences were very small but were statistically significant, whereas LHV of the biomass after extraction with $\mathrm{scCO}_{2}$ was significantly higher compared to the biomass before extraction and extraction with the addition of water to carbon dioxide $\left(\mathrm{CO}_{2} / \mathrm{H}_{2} \mathrm{O}\right)$ by 3.6 and $5.1 \%$, respectively. The greater variation within LHV in comparison with HHV resulted mainly indirectly from the variation in the moisture content of raw materials, due to the fact that LHV is a function of moisture content, HHV and the content of hydrogen. When comparing the types of biomass in terms of HHV, higher values of this characteristic were found for the SRC, especially when compared to herbaceous crops as well as grasses (Fig. 12). However, in the case of LHV, the highest values of this feature were found for all 19 types of biomass after extraction with pure $\mathrm{scCO}_{2}$ (Fig. 13). The LHV value for this type of biomass ranged from 16.34 to $17.84 \mathrm{MJ} \mathrm{kg}^{-1}$ for $S$. perfoliatum and P. nigra $x$ P. maximowiczii (w), respectively. In addition, it should be emphasized that $\mathrm{LHV}$ of all 19 types of biomass, both after extraction with pure $\mathrm{scCO}_{2}$ as well as $\mathrm{scCO}_{2} / \mathrm{H}_{2} \mathrm{O}$ (range from 15.53 to $17.19 \mathrm{MJ} \mathrm{kg}^{-1}$ ) and the biomass before extraction (range from 15.68 to $17.19 \mathrm{MJ} \mathrm{kg}^{-1}$ ), was higher compared to the biomass harvested directly from the plantation. This was mainly due to the low moisture content as shown in the present results. In other studies, it was shown that the LHV of the PIC biomass obtained directly from the plantations was significantly differentiated both by the species and by the harvest date (Stolarski et al. 2018). With the high moisture content of the biomass harvested from the plantation in winter, the LHV was 
Table 4 Factor loads of principal component analysis with varimax rotation

\begin{tabular}{|c|c|c|c|c|c|c|c|c|c|}
\hline \multirow[t]{2}{*}{ Variable } & \multicolumn{3}{|c|}{ Biomass before extraction } & \multicolumn{3}{|c|}{$\begin{array}{l}\text { Biomass after pure } \mathrm{scCO}_{2} \\
\text { extraction }\end{array}$} & \multicolumn{3}{|c|}{$\begin{array}{l}\text { Biomass after } \mathrm{scCO}_{2} / \mathrm{H}_{2} \mathrm{O} \\
\text { extraction }\end{array}$} \\
\hline & PC1 & $\mathrm{PC} 2$ & PC3 & $\mathrm{PC} 1$ & PC2 & PC3 & $\mathrm{PC} 1$ & $\mathrm{PC} 2$ & PC3 \\
\hline Moisture & 0.71 & -0.33 & 0.50 & 0.67 & -0.46 & 0.25 & 0.26 & -0.26 & -0.80 \\
\hline HHV & 0.43 & 0.81 & 0.27 & 0.43 & $\mathbf{0 . 8 0}$ & 0.28 & 0.30 & 0.85 & -0.29 \\
\hline LHV & 0.05 & 0.97 & -0.01 & 0.12 & 0.93 & 0.13 & 0.17 & 0.87 & 0.19 \\
\hline Ash & 0.71 & -0.59 & -0.24 & 0.68 & -0.58 & -0.25 & 0.62 & -0.55 & 0.39 \\
\hline $\mathrm{N}$ & 0.86 & 0.21 & 0.13 & 0.86 & 0.20 & 0.16 & 0.86 & 0.11 & -0.24 \\
\hline $\mathrm{C}$ & -0.29 & 0.81 & 0.27 & -0.31 & 0.76 & 0.22 & -0.31 & 0.84 & -0.27 \\
\hline $\mathrm{H}$ & 0.09 & 0.84 & 0.32 & -0.03 & 0.59 & 0.27 & -0.28 & 0.73 & 0.09 \\
\hline $\mathrm{S}$ & 0.96 & -0.02 & -0.03 & 0.93 & 0.07 & -0.12 & 0.96 & 0.06 & 0.08 \\
\hline $\mathrm{Cl}$ & -0.02 & -0.42 & -0.77 & -0.04 & -0.33 & -0.82 & 0.00 & -0.39 & 0.71 \\
\hline $\begin{array}{c}\text { Compounds } \\
\text { soluble in } \\
\text { cold water }\end{array}$ & 0.89 & 0.18 & 0.30 & 0.85 & 0.09 & 0.37 & 0.88 & -0.06 & -0.39 \\
\hline $\begin{array}{c}\text { Compounds } \\
\text { soluble in } \\
\text { hot water }\end{array}$ & 0.91 & 0.14 & 0.27 & 0.89 & 0.04 & 0.33 & 0.90 & -0.09 & -0.34 \\
\hline $\begin{array}{l}\text { Other soluble } \\
\text { substances }\end{array}$ & 0.87 & -0.14 & 0.41 & 0.92 & -0.15 & 0.30 & 0.90 & -0.26 & -0.23 \\
\hline Hemicellulose & -0.38 & -0.27 & -0.84 & -0.37 & -0.17 & -0.86 & -0.39 & 0.08 & 0.86 \\
\hline Cellulose & -0.98 & -0.09 & -0.08 & -0.98 & 0.00 & -0.07 & -0.97 & 0.03 & 0.13 \\
\hline Lignin & 0.36 & 0.58 & 0.66 & 0.22 & 0.45 & 0.72 & 0.15 & 0.23 & -0.84 \\
\hline $\begin{array}{l}\text { Eigenvalue } \\
\qquad\left(\lambda_{\mathrm{i}}\right)\end{array}$ & 6.57 & 4.13 & 2.64 & 6.34 & 3.39 & 2.66 & 6.34 & 3.39 & 2.66 \\
\hline $\begin{array}{r}\text { Explained } \\
\text { variance }\end{array}$ & $43.8 \%$ & $27.5 \%$ & $17.6 \%$ & $42.3 \%$ & $22.6 \%$ & $17.7 \%$ & $42.3 \%$ & $22.6 \%$ & $17.7 \%$ \\
\hline
\end{tabular}

Bold values indicate significance

even 2-3 times lower compared to that found in post-extraction biomass. In the cited studies, the effect of the harvest date on LHV of herbaceous crops and grasses biomass was definitely higher (no such relationship was found for SRC). In the biomass harvested at the end of March, due to its natural drying, the LHV for H. tuberosus and $M$. sacchariflorus was high and amounted to 15.2 and $15.9 \mathrm{MJ} \mathrm{kg}^{-1}$, respectively. High values of LHV biomass of herbaceous crops and grasses obtained in spring were also studied by other authors (Kalembasa and Malinowska 2008; Komorowicz et al. 2009; Tworkowski et al. 2014).

\section{PCA analysis and impact assessment of PIC group on the biomass properties}

In order to clearly illustrate the test results obtained within each extraction group, fifteen selected biomass features of the studied PIC species were subjected to multidimensional PCA analysis. In each case, this analysis separated three principal 
Fig. 14 Biplot chart for the biomass before extraction (points 1 to 19 refer to the ID according to Table 1)

Fig. 15 Biplot chart for the biomass after pure $\mathrm{scCO}_{2}$ extraction (points 1 to 19 refer to the ID according to Table 1)
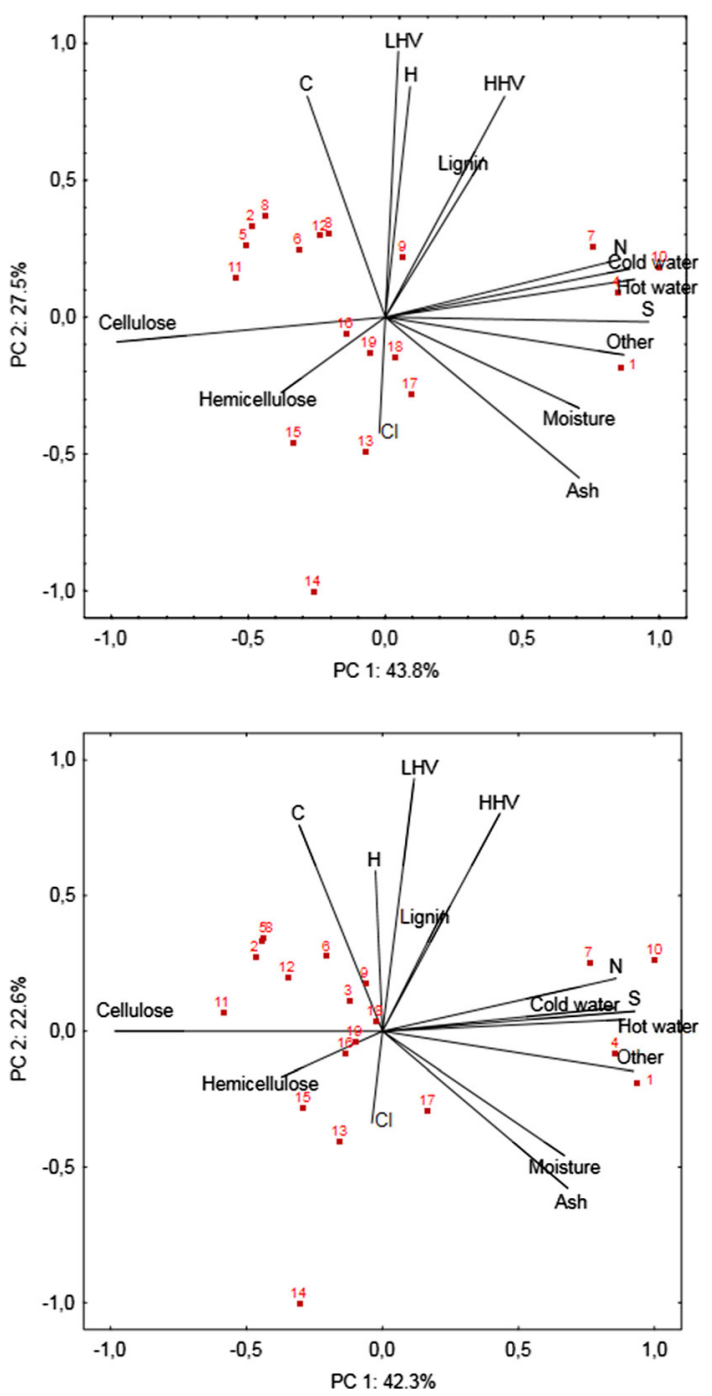

components (PC1, PC2 and PC3), which together explained $88.9 \%$ in biomass before extraction and $82.6 \%$ in biomass after extraction with pure $\mathrm{scCO}_{2}$ and $\mathrm{scCO}_{2} / \mathrm{H}_{2} \mathrm{O}$ (Table 4). In the biomass before extraction, the first principal component (PC1) included the content of moisture, ash, nitrogen, sulfur, substances soluble in cold and hot water, other soluble substances and cellulose with the opposite sign to other features. In general, it can be said that the PC1 component described what influenced the cellulose content of the studied objects. This component (PC1) explained $43.8 \%$ of variance. The biplot chart of this group (Fig. 14) indicated that the bark of all four SRC species formed a cluster of similar objects that combined high values for the content of nitrogen, sulfur, substances soluble in cold and hot water, other substances soluble and low cellulose content. The last feature (the cellulose content) distinguished 
Fig. 16 Biplot chart for the biomass after $\mathrm{scCO}_{2} / \mathrm{H}_{2} \mathrm{O}$ extraction (points 1 to 19 refer to the ID according to Table 1)

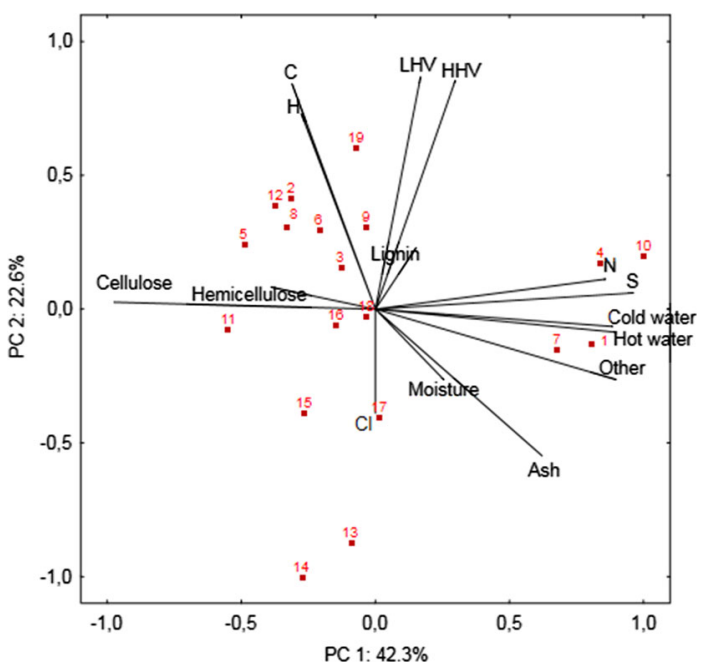

objects lying on the opposite side of the biplot, and it was primarily wood of all SRC species. The features of HHV, LHV and the content of $\mathrm{C}$ and $\mathrm{H}$ in the biomass were the second component of the PCA analysis, which may be generally referred to as biomass energy value (Table 4). The higher the points of the examined objects are placed on the biplot chart, the higher the value of these features. On the other hand, the lower the points of the examined objects are placed, as for instance the biomass of $S$. perfoliatum (14), H. salicifolius (13), H. tuberosus (15) or M. sinensis (17), the lower the value of HHV, LHV, C and H (Fig. 14). However, all points lying in the center of the biplot are assigned to types of biomass with average values of the PC1 and PC2 component features. The last third component (PC3) is the content of chlorine, hemicellulose and the inversely correlated lignin content. In general terms, the PC3 component described hemicellulose and lignin content. This component explained less than $18 \%$ of variance (Table 4). Similar relationships were observed in both extraction groups: pure $\mathrm{scCO}_{2}$ and $\mathrm{scCO}_{2} / \mathrm{H}_{2} \mathrm{O}$. The exception was only moisture content, found in PC3 after $\mathrm{scCO}_{2} / \mathrm{H}_{2} \mathrm{O}$ extraction (Table 4, Figs. 15, 16).

The present research shows that the chemical composition and thermophysical properties of the PIC biomass obtained in 1-year harvest cycles were very diverse. The quality of the biomass was determined in particular by the PIC species and the type of biomass: bark, wood, wood with bark, semi-wood and straw (Table 5). It was generally shown that bark biomass of all four SRC species had high content of nitrogen, sulfur, substances soluble in cold and hot water, other soluble substances and at the same time a low cellulose content. In turn, the wood of all SRC species was distinguished by a high cellulose content, whereas semi-woody biomass from the herbaceous crops group was characterized by lower HHV, LHV and carbon values. In addition, all herbaceous crops and grasses contained more chlorine, hemicellulose and generally less lignin compared to the SRC biomass. 
Table 5 Average values of all tested biomass features depending on perennial industrial crops group and biomass type**

\begin{tabular}{|c|c|c|c|c|c|c|}
\hline Item & Unit & $\begin{array}{l}\text { Short- } \\
\text { rotation } \\
\text { coppice } \\
(\mathrm{b})^{*}\end{array}$ & $\begin{array}{l}\text { Short- } \\
\text { rotation } \\
\text { coppice } \\
(\mathrm{w})^{*}\end{array}$ & $\begin{array}{l}\text { Short- } \\
\text { rotation } \\
\text { coppice (b } \\
+\mathrm{w})^{*}\end{array}$ & $\begin{array}{l}\text { Herbaceous } \\
\text { crops } \\
(\mathrm{s}-\mathrm{w})^{*}\end{array}$ & Grasses $(\mathrm{s})^{*}$ \\
\hline $\begin{array}{r}\text { Moisture } \\
\text { content }\end{array}$ & $\%$ & $6.93^{a}$ & $5.35^{\mathrm{b}}$ & $5.47^{\mathrm{b}}$ & $6.07^{\mathrm{ab}}$ & $5.12^{b}$ \\
\hline Ash & $\%$ d.m. & $3.89^{\mathrm{a}}$ & $0.65^{d}$ & $1.40^{\mathrm{c}}$ & $3.67^{\mathrm{a}}$ & $3.21^{\mathrm{b}}$ \\
\hline HHV & $\begin{array}{c}\mathrm{MJ} \mathrm{kg}^{-1} \\
\text { d.m. }\end{array}$ & $19.58^{\mathrm{a}}$ & $19.36^{b}$ & $19.42^{b}$ & $18.55^{d}$ & $18.99^{c}$ \\
\hline LHV & $\mathrm{MJ} \mathrm{kg}^{-1}$ & $16.96^{\mathrm{ab}}$ & $17.05^{\mathrm{a}}$ & $17.08^{\mathrm{a}}$ & $16.22^{\mathrm{c}}$ & $16.79^{b}$ \\
\hline $\mathrm{C}$ & $\%$ d.m. & $53.22^{\mathrm{b}}$ & $55.71^{\mathrm{a}}$ & $54.86^{\mathrm{a}}$ & $51.27^{\mathrm{c}}$ & $52.69^{b c}$ \\
\hline $\mathrm{H}$ & $\%$ d.m. & $5.77^{\mathrm{a}}$ & $5.88^{\mathrm{a}}$ & $5.91^{\mathrm{a}}$ & $5.66^{\mathrm{ab}}$ & $5.52^{\mathrm{b}}$ \\
\hline $\mathrm{N}$ & $\%$ d.m. & $1.90^{\mathrm{a}}$ & $0.47^{\mathrm{c}}$ & $0.76^{\mathrm{b}}$ & $0.49^{c}$ & $0.54^{\mathrm{c}}$ \\
\hline $\mathrm{S}$ & $\%$ d.m. & $0.089^{\mathrm{a}}$ & $0.029^{\mathrm{e}}$ & $0.046^{\mathrm{c}}$ & $0.035^{\mathrm{d}}$ & $0.055^{\mathrm{b}}$ \\
\hline $\mathrm{Cl}$ & $\%$ d.m. & $0.042^{\mathrm{c}}$ & $0.028^{c}$ & $0.034^{\mathrm{c}}$ & $0.135^{\mathrm{b}}$ & $0.225^{\mathrm{a}}$ \\
\hline $\begin{array}{l}\text { Compounds } \\
\text { soluble in } \\
\text { cold } \\
\text { water }\end{array}$ & $\%$ d.m. & $21.08^{\mathrm{a}}$ & $5.86^{\mathrm{cd}}$ & $7.52^{b}$ & $6.31^{c}$ & $4.61^{\mathrm{d}}$ \\
\hline $\begin{array}{c}\text { Compounds } \\
\text { soluble in } \\
\text { hot water }\end{array}$ & $\%$ d.m. & $26.38^{\mathrm{a}}$ & $7.37^{\mathrm{c}}$ & $10.31^{b}$ & $8.67^{b c}$ & $7.40^{\mathrm{c}}$ \\
\hline $\begin{array}{l}\text { Other } \\
\text { soluble } \\
\text { sub- } \\
\text { stances }\end{array}$ & $\%$ d.m. & $16.12^{\mathrm{a}}$ & $3.07^{\mathrm{d}}$ & $6.30^{c}$ & $8.29^{\mathrm{b}}$ & $4.23^{\mathrm{d}}$ \\
\hline Hemicellulose & $\%$ d.m. & $11.51^{\mathrm{d}}$ & $18.44^{b c}$ & $16.56^{\mathrm{c}}$ & $18.68^{b}$ & $31.65^{\mathrm{a}}$ \\
\hline Cellulose & $\%$ d.m. & $26.87^{\mathrm{d}}$ & $53.89^{\mathrm{a}}$ & $48.29^{b c}$ & $50.01^{b}$ & $47.44^{\mathrm{c}}$ \\
\hline Lignin & $\%$ d.m. & $19.11^{\mathrm{a}}$ & $17.22^{\mathrm{b}}$ & $18.54^{\mathrm{ab}}$ & $14.36^{\mathrm{c}}$ & $9.28^{d}$ \\
\hline
\end{tabular}

*Explanations_-see Table 1

$* * a, b, c$ _ the values in the lines marked with the same letter do not differ statistically (Tukey's HSD test with $P<0.05)$

\section{Conclusion}

The PIC biomass quality was determined by species and biomass type (bark, wood, wood with bark, semi-wood, straw) and by the type of extraction (pure $\mathrm{scCO}_{2}$ and $\left.\mathrm{scCO}_{2} / \mathrm{H}_{2} \mathrm{O}\right)$. It was shown that after both types of extraction $\left(\mathrm{scCO}_{2}\right.$ and $\left.\mathrm{scCO}_{2} / \mathrm{H}_{2} \mathrm{O}\right)$, the biomass moisture content was below $10 \%$, which means that it can be successfully used for further processes or can be stored without losing its properties or value. It was also found that the biomass after extraction with pure $\mathrm{scCO}_{2}$ and $\mathrm{scCO}_{2} / \mathrm{H}_{2} \mathrm{O}$ contained less ash, carbon, hydrogen, nitrogen, sulfur, lignin, hemicellulose and more chlorine compared to the biomass before extraction. Moreover, the biomass after extraction with pure $\mathrm{scCO}_{2}$ contained more cellulose and had lower moisture content and higher 
$\mathrm{HHV}$ and $\mathrm{LHV}$ values. However, the biomass after $\mathrm{scCO}_{2} / \mathrm{H}_{2} \mathrm{O}$ extraction contained more substances soluble in cold and hot water.

The present results provide valuable and important information on changes in thermophysical properties and chemical composition of the PIC lignocellulosic biomass. Moreover, the post-extraction (pure $\mathrm{scCO}_{2}$ and $\mathrm{scCO}_{2} / \mathrm{H}_{2} \mathrm{O}$ ) residues, which are a byproduct, may be further used in a biorefinery or simply energy. Therefore, the present results can be used by other researchers and people involved in the production and use of PIC lignocellulosic biomass in the bioeconomy. Depending on the market demand for a given type of biomass with a specific composition, it is potentially possible to plan the production of the selected PIC species, followed by the entire logistics chain of biomass processing. However, in order to fully assess the usefulness of the PIC extraction biomass for the production of solid, liquid or gaseous biofuels, further research is needed. It should also be added and strongly emphasized that the biomass is not extracted in order to modify its properties but in order to obtain bioactive substances and other phytochemicals for bioproduct manufacturing. Acquisition of the largest possible amount of bioactive substances from a specified amount of biomass and in relation to, for instance, the surface unit from which the plant was obtained is also a key issue. Therefore, the issues of assessing the efficiency of supercritical extraction with pure $\mathrm{scCO}_{2}$ and $\mathrm{scCO}_{2} / \mathrm{H}_{2} \mathrm{O}$ and the potential yield of the extract that can be obtained from the PIC cultivation area of 1 ha as well as the use of post-extraction biomass will be the subject of future work.

Acknowledgements This study was co-financed by the National (Polish) Centre for Research and Development (NCBiR), entitled "Environment, agriculture and forestry," project: BIOproducts from lignocellulosic biomass derived from MArginal land to fill the Gap In Current national bioeconomy, No. BIOSTRATEG3/344253/2/NCBR/2017. We would also like to thank the staff of the Department of Plant Breeding and Seed Production, Didactic and Research Station in Łężany and Bałdy and also for Quercus Sp. z o.o. company for their technical support during the experiment.

\section{Compliance with ethical standards}

Conflict of interest On behalf of all authors, the corresponding author states that there is no conflict of interest.

Open Access This article is licensed under a Creative Commons Attribution 4.0 International License, which permits use, sharing, adaptation, distribution and reproduction in any medium or format, as long as you give appropriate credit to the original author(s) and the source, provide a link to the Creative Commons licence, and indicate if changes were made. The images or other third party material in this article are included in the article's Creative Commons licence, unless indicated otherwise in a credit line to the material. If material is not included in the article's Creative Commons licence and your intended use is not permitted by statutory regulation or exceeds the permitted use, you will need to obtain permission directly from the copyright holder. To view a copy of this licence, visit http://creativecommons.org/licenses/by/4.0/.

\section{References}

Attard TM, Arshadi M, Nilsson C, Budarin VL, Valencia-Reyes E, Clark JH, Hunt AJ (2016) Impact of supercritical extraction on solid fuel wood pellet properties and off-gassing during storage. Green Chem 18(9):2682-2690 
Attard TM, Bukhanko N, Eriksson D, Arshadi M, Geladi P, Bergsten U, Budarin VL, Clark JH, Hunt AJ (2018) Supercritical extraction of waxes and lipids from biomass: a valuable first step towards an integrated biorefinery. J Clean Prod 177:684-698

Bonaterra GA, Heinrich EU, Kelber O, Weiser D, Metz J, Kinscherf R (2010) Anti-inflammatory effects of the willow bark extract STW 33-I (Proaktiv $\left({ }^{\circledR}\right)$ ) in LPS-activated human monocytes and differentiated macrophages. Phytomedicine 17(14):1106-1113

Ceotto E, Castelli F, Moschella A, Diozzi M, Di Candilo M (2015) Cattle slurry fertilization to giant reed (Arundo donax L.): biomass yield and nitrogen use efficiency. Bioenergy Res 8:1252-1262

Ceotto E, Castelli F, Moschella A, Diozzi M, Di Candilo M (2016) Poplar short rotation coppice is not a first choice crop for cattle slurry fertilization: biomass yield and nitrogen-use efficiency. Ind Crops Prod 85:167-173

Christian DG, Riche AB, Yates NE (2008) Growth, yield and mineral content of Miscanthus x giganteus grown as a biofuel for 14 successive harvests. Ind Crops Prod 28:320-327

Conde E, Fang W, Hemming J, Willför S, Domínguez H, Parajó JC (2014) Recovery of bioactive compounds from Pinus pinaster wood by consecutive extraction stages. Wood Sci Technol 48:311-323

Cuiping L, Chuangzhi W, Yanyongjie B, Haitao H (2004) Chemical elemental characteristic of biomass fuels in China. Biomass Bioenergy 27:130-199

Dawson BSW, Pearson $\mathrm{H}$ (2017) Effect of supercritical $\mathrm{CO}_{2}$ dewatering followed by oven-drying of softwood and hardwood timbers. Wood Sci Technol 51:771-784

Devappa RK, Rakshit SK, Dekker RFH (2015) Forest biorefinery: Potential of poplar phytochemicals as value-added co-products. Biotechnol Adv 33(6 Part 1):681-716

FOSS AN 304-Fibre determination using the Fibertec 2010 \& M6

Gasol CM, Brun F, Mosso A, Rieradevall J, Gabarrell X (2010) Economic assessment and comparison of acacia energy crop with annual traditional crops in Southern Europe. Energy Policy 38:592-597

Godin B, Lamaudière S, Agneessens R, Schmit T, Goffart JP, Stilmant D, Gerin PA, Delcarte J (2013) Chemical characteristics and biofuel potential of several vegetal biomasses grown under a wide range of environmental conditions. Ind Crops Prod 48:1-12

Haghighi Mood S, Hossein Golfeshan A, Tabatabaei M, Salehi Jouzani G, Najafi GH, Gholami M, Ardjmand M (2013) Lignocellulosic biomass to bioethanol, a comprehensive review with a focus on pretreatment. Renew Sust Energy Rev 27:77-93

Jankowski KJ, Dubis B, Budzyński WS, Bórawski P, Bułkowska K (2016) Energy efficiency of crops grown for biogas production in a large-scale farm in Poland. Energy 109:277-286

Kalembasa D, Malinowska E (2008) The influence of doses of waste activated sludge on the yield of Miscanthus sacchariflorus [Maxim.] Hack., biomass, sulfur content and energetic value. Zesz Probl Post Nauk Rol 533:173-179 (in Polish with English Summary)

Komorowicz M, Wróblewska H, Pawłowski J (2009) Chemical composition and energetic properties of biomass from selected renewable resources. Ochr Środ Zasob Nat 40:402-410 (in Polish with English Summary)

Krzyżaniak M, Stolarski MJ, Waliszewska B, Szczukowski S, Tworkowski J, Załuski D, Śnieg M (2014) Willow biomass as feedstock for an integrated multi-product biorefinery. Ind Crops Prod 58:230-237

Krzyżaniak M, Stolarski MJ, Szczukowski S, Tworkowski J (2015) Thermophysical and chemical properties of biomass obtained from willow coppice cultivated in one- and three-year rotation cycles. J Elem $1: 161-175$

Matyka M, Kuś J (2016) Influence of soil quality for yielding and biometric features of Miscanthus $\times$ Giganteus. Pol J Environ Stud 25(1):213-219

McElroy CR, Attard TM, Farmer TJ, Gaczynski A, Thornthwaite D, Clark JH, Hunt AJ (2017) Valorization of spruce needle waste via supercritical extraction of waxes and facile isolation of nonacosan-10-ol. J Clean Prod 171:557-566

Monedero E, Hernández JJ, Cañellas I, Otero JM, Sixto H(2016) Thermochemical and physical evaluation of poplar genotypes as short rotation forestry crops for energy use. Energy Convers Manage 129:131-139

Monti A, Zanetti F, Scordia D, Testa G, Cosentino SL (2015) What to harvest when? Autumn, winter, annual and biennial harvesting of giant reed, miscanthus and switchgrass in northern and southern Mediterranean area. Ind Crops Prod 75:129-134

Morais ARC, da Costa Lopes AM, Bogel-Łukasik R (2015) Carbon dioxide in biomass processing: contributions to the green biorefinery concept. Chem Rev 115:3-27

Neata G, Campeanu G, Popescu MI, Popa O, Babeanu N, Basaraba A, Popescu DD (2015) Lignin extraction from corn biomass using supercritical extraction. Rom Biotech Lett 20(3):10406-10412 
Nielsen HK, Laerke PE, Liu N, Jorgensen U (2015) Sampling procedure in a willow plantation for estimation of moisture content. Biomass Bioenergy 78:62-70

Noleto-Dias C, Ward JL, Bellisai A, Lomax C, Beale MH (2018) Salicin-7-sulfate: a new salicinoid from willow and implications for herbal medicine. Fitoterapia 127:166-172

Parajuli R, Knudsen MT, Dalgaard T (2015) Multi-criteria assessment of yellow, green, and woody biomasses: pre-screening of potential biomasses as feedstocks for biorafineries. Biofuels Bioprod Bioref 9:545-566

Pasquini D, Pimenta MTB, Ferreira LH, Curvelo AAS (2005) Sugar cane bagasse pulping using supercritical $\mathrm{CO}_{2}$ associated with co-solvent 1-butanol/water. J Supercrit Fluids 34:125-131

PN-EN ISO 13906:2009 (2009) Determination of acid detergent fibre (ADF) and acid detergent lignin (ADL) contents. Polish Committee for Standardization, Warsaw

PN-EN ISO 16472:2007 (2007) Determination of amylase-treated neutral detergent fibre content (aNDF). Polish Committee for Standardization, Warsaw

PN-EN ISO 16948:2015-07 (2015) Solid biofuels-Determination of total content of carbon, hydrogen and nitrogen. Polish Committee for Standardization, Warsaw

PN-EN ISO 16994:2016-10 (2016) Solid biofuels-Determination of total content of sulfur and chlorine. Polish Committee for Standardization, Warsaw

PN-EN ISO 18125:2017-07 (2017) Solid biofuels-Determination of calorific value. Polish Committee for Standardization, Warsaw

PN-EN ISO 18134-1:2015-11 (2015) Solid biofuels-Determination of moisture content-Oven dry method-Part 1: Total moisture-Reference method. Polish Committee for Standardization, Warsaw

PN-EN ISO 14780:2017-07 (2017) Solid biofuels-Sample preparation. Polish Committee for Standardization, Warsaw

PN-EN ISO 18122:2016-01 (2016) Solid biofuels-Determination of ash content. Polish Committee for Standardization, Warsaw

PN-ISO 587:2000 (2000) Solid fuels-Determination of chlorine using Eschka mixture. Polish Committee for Standardization, Warsaw

Przybysz K, Małachowska E, Martyniak D, Boruszewski P, Iłowska J, Kalinowska H, Przybysz P (2018) Yield of pulp, dimensional properties of fibers and properties of paper produced from fast growing trees and grasses. BioResources 13(1):1372-1387

Rój E (2014) Plant material extraction using supercritical $\mathrm{CO}_{2}$. In: book: Supercritical $\mathrm{CO}_{2}$ extraction and its application, Polish Foundation of the Opportunities Industrialization Centers "OIC Poland", Lublin 2014. DOI:10.13140/2.1.3565.9207

Sabatti M, Fabbrini F, Harfouche A, Beritogenolo I, Mareschi L, Carlini M, Paris P, Scarascia-Mugnozza G (2014) Evaluation of biomass production potential and heating value of hybrid poplar genotypes in a short-rotation culture in Italy. Ind Crops Prod 61:62-73

Schrems M, Liebner F, Betz M, Zeilinger M, Böhmdorfer S, Rosenau T, Potthast A (2012) Understanding the impact of supercritical carbon dioxide on the delignification mechanism during organosolv pulping: a model compound study. J Wood Chem Technol 32:225-237

Scordia D, van den Berg D, van Sleen P, Alexopoulou E, Cosentino SL (2016) Are herbaceous perennial grasses suitable feedstock for thermochemical conversion pathways? Ind Crops Prod 91:350-357

Sergent T, Kohnen S, Jourez B, Beauve C, Schneider YJ, Vincke C (2014) Characterization of black locust (Robinia pseudoacacia L.) heartwood extractives: Identification of resveratrol and piceatannol. Wood Sci Technol 48(5):1005-1017

Stolarski M, Wróblewska H, Cichy W, Szczukowski S, Tworkowski J (2005) Chemical composition and calorific value of basket willow wood obtained from arable lands. Drewno 48(174):5-16 (in Polish with English Summary)

Stolarski MJ, Krzyżaniak M, Waliszewska B, Szczukowski S, Tworkowski J, Zaborowska M (2013a) Lignocellulosic biomass derived from agricultural land as industrial and energy feedstock. Drewno 56:5-23

Stolarski MJ, Szczukowski S, Tworkowski J, Krzyżaniak M (2013b) Cost of heat energy generation from willow biomass. Renew Energy 59:100-104

Stolarski MJ, Krzyżaniak M, Warmiński K, Śnieg M (2013c) Energy, economic and environmental assessment of heating a family house with biomass. Energy Build 66:395-404

Stolarski MJ, Krzyżaniak M, Śnieg M, Słomińska E, Piórkowski M, Filipkowski R (2014) Thermophysical and chemical properties of perennial energy crops depending on harvest period. Int Agrophysic 28:201-211 
Stolarski MJ, Krzyżaniak M, Łuczyński M, Załuski D, Szczukowski S, Tworkowski J, Gołaszewski J (2015a) Lignocellulosic biomass from short rotation woody crops as a feedstock for second-generation bioethanol production. Ind Crops Prod 75:66-75

Stolarski MJ, Mleczek M, Szczukowski S, Goliński P, Waliszewska B, Szentner K, Rutkowski P, Krzyżaniak M (2015b) Characteristics if thermophysical parameters of selected Salix taxa with elemental analysis. Int J Green Energy 12:1272-1279

Stolarski MJ, Krzyżaniak M, Warmiński K, Tworkowski J, Szczukowski S (2017) Perennial herbaceous crops as a feedstock for energy and industrial purposes: organic and mineral fertilizers versus biomass yield and efficient nitrogen utilization. Ind Crops Prod 107:244-259

Stolarski MJ, Śnieg M, Krzyżaniak M, Tworkowski J, Szczukowski S, Graban Ł, Lajszner W (2018) Short rotation coppices, grasses and other herbaceous crops: biomass properties versus 26 genotypes and harvest time. Ind Crops Prod 119:22-32

TIBCO Software Inc (2017) Statistica (data analysis software system), version 13. http://statistica.io

Tworkowski J, Szczukowski S, Stolarski MJ, Kwiatkowski J, Graban Ł (2014) Productivity and properties of Virginia fanpetals biomass as fuel depending on the propagule and plant density. Fragm Agron 31:115-125 (in Polish with English Summary)

Vázquez G, Santos J, Freire SM, Antorrena G, González-Álvarez J (2012) Extraction of antioxidants from eucalyptus (Eucalyptus globulus) bark. Wood Sci Technol 46:443-457

Wang S, Luo K, Wang X, Sun Y (2016) Estimate of sulfur, arsenic, mercury, fluorine emission due to spontaneous combustion of coal gangue: an important part of Chinese emission inventories. Environ Pollut 209:107-113

Publisher's Note Springer Nature remains neutral with regard to jurisdictional claims in published maps and institutional affiliations.

\section{Affiliations}

\section{Mariusz Jerzy Stolarski ${ }^{1,3} \cdot$ Kazimierz Warmiński ${ }^{2,3} \cdot$ Michał Krzyżaniak $^{1,3}$. Katarzyna Tyśkiewicz ${ }^{4}$ Ewelina Olba-Zięty ${ }^{1,3}$ • Łukasz Graban ${ }^{1}$. Waldemar Lajszner ${ }^{1}$ - Dariusz Załuski ${ }^{1}$ - Rafał Wiejak ${ }^{4}$. Piotr Kamiński ${ }^{4}$. Edward Rój ${ }^{4}$}

$凶 \quad$ Mariusz Jerzy Stolarski

mariusz.stolarski@uwm.edu.pl

1 Department of Plant Breeding and Seed Production, Faculty of Environmental Management and Agriculture, University of Warmia and Mazury in Olsztyn, Plac Łódzki 3, 10-724 Olsztyn, Poland

2 Department of Chemistry, Faculty of Environmental Management and Agriculture, University of Warmia and Mazury in Olsztyn, Prawocheńskiego 17, 10-720 Olsztyn, Poland

3 Centre for Bioeconomy and Renewable Energies, University of Warmia and Mazury in Olsztyn, Plac Łódzki 3, 10-724 Olsztyn, Poland

4 Supercritical Extraction Department, ŁUKASIEWICZ Research Network - New Chemical Syntheses Institute, Al. Tysiąclecia Państwa Polskiego 13A, 24-110 Puławy, Poland 